\title{
24. PALEOMAGNETIC STUDIES OF BASALT SAMPLES, DEEP SEA DRILLING PROJECT, LEG 25
}

\author{
J. Wolejszo, R. Schlich, and J. Segoufin, Institut de Physique du Globe de Paris, \\ Saint-Maur-Des-Fossés, France
}

\section{INTRODUCTION}

Basalt cores were recovered from five sites drilled in the western Indian Ocean during Leg 25 (Sites 239, 240, 245, 248 , and 249). The 1.2-meter basalt core from Site 240 appeared highly fractured and was not sampled for paleomagnetism. At Sites 239, 245, 248, and 249, fresh appearing basalt was recovered and nine samples were taken for paleomagnetic studies. These samples are listed in Table 1 with their geographic location and geometric characteristics. All the samples are identified by a shorthand numbering system which gives their geographical location and their position in the hole and core (see Chapter 1, explanatory notes). The two samples from Site 239 have been given an additional numerical designation. For Site 248, one of the samples used for this study was found in the drill string after retrieving the pipes. This sample belongs without doubt to the last core cut at this site and is designated 248-17, BHA (bottom hole assembly). The cylindrical shape of this sample provides its orientation to the axis of the hole and from paleomagnetic measurements made on the specimens sampled in the same core, it is possible to identify the top and bottom of the sample.

Oriented (Azimuth) cores were not obtained on board Glomar Challenger, thus, the only known direction for each sample is the axis of the hole which is close to the vertical. Several measurements of the inclination of the holes drilled were made at Sites 239, 242, 245, 248, and 249. The results are given in Table 2 and indicate that the holes were never more than $5^{\circ}$ from the vertical. The vertical direction $(+z)$ is taken positive downwards, the $x$ and $y$ directions, in the horizontal plane, are chosen arbitrarily but are consistent for subsamples cut from the same sample as listed in Table 1.

At Site 239, the hole penetrated 320 meters of sediments and 6 meters into the underlying basaltic basement, which can be considered as true "oceanic basement". The basalt ( $2.2 \mathrm{~m}$ recovery in Cores 20 and 21 ) is dark gray, fine-grained, partly glassy, and similar in

TABLE 1

Geographic Locations and Geometric Characteristics of Basalt Samples

\begin{tabular}{lcrc}
\hline \multicolumn{1}{c}{ Sample } & \multicolumn{1}{c}{ Location } & $\begin{array}{c}\text { Length } \\
(\mathrm{cm})\end{array}$ & $\begin{array}{c}\text { Diameter } \\
(\mathrm{cm})\end{array}$ \\
\hline $239-21-1,12-18 \mathrm{~cm}$ (No. 1) & $21^{\circ} 17.67^{\prime} \mathrm{S}, 51^{\circ} 40.73^{\prime} \mathrm{E}$ & 6 & 5.5 \\
$239-21-1,137-148 \mathrm{~cm}$ (No. 17) & $21^{\circ} 17.67^{\prime} \mathrm{S}, 51^{\circ} 40.73^{\prime} \mathrm{E}$ & 11 & 5.5 \\
$245-19-1,71-74 \mathrm{~cm}$ & $31^{\circ} 32.02^{\prime} \mathrm{S}, 52^{\circ} 18.11^{\prime} \mathrm{E}$ & 4 & 6.0 \\
$245-19-1,82-85 \mathrm{~cm}$ & $31^{\circ} 32.02^{\prime} \mathrm{S}, 52^{\circ} 18.11^{\prime} \mathrm{E}$ & 3 & 6.0 \\
$248-15-1,25-33 \mathrm{~cm}$ & $29^{\circ} 31.78^{\prime} \mathrm{S}, 37^{\circ} 28.48^{\prime} \mathrm{E}$ & 7 & 5.5 \\
$248-17-1,140-144 \mathrm{~cm}$ & $29^{\circ} 31.78^{\prime} \mathrm{S}, 37^{\circ} 28.48^{\prime} \mathrm{E}$ & 4 & 5.5 \\
$248-17, \mathrm{BHA}$ & $29^{\circ} 31.78^{\prime} \mathrm{S}, 37^{\circ} 28.48^{\prime} \mathrm{E}$ & 9 & 5.6 \\
$249-33,3-50-57 \mathrm{~cm}$ & $29^{\circ} 56.99^{\prime} \mathrm{S}, 36^{\circ} 04.62^{\prime} \mathrm{E}$ & 8 & 5.8 \\
$249-33, \mathrm{CC}$ & $29^{\circ} 56.99^{\prime} \mathrm{S}, 36^{\circ} 04.62^{\prime} \mathrm{E}$ & 6 & 5.8 \\
\hline
\end{tabular}

TABLE 2

Downhole Inclinometer Measurements, Leg 25

\begin{tabular}{ccccc}
\hline Site & $\begin{array}{c}\text { Water Depth } \\
(\mathrm{m})\end{array}$ & $\begin{array}{c}\text { Subbottom Depth } \\
\text { of Measurements } \\
(\mathrm{m})\end{array}$ & $\begin{array}{c}\text { Total } \\
\text { Penetration } \\
(\mathrm{m})\end{array}$ & $\begin{array}{c}\text { Deviation From } \\
\text { Vertical } \\
(\text { degree })\end{array}$ \\
\hline 239 & 4971 & 300 & 326 & 5 \\
239 & 4971 & 320 & 326 & 5 \\
242 & 2275 & 140 & 676 & 2 \\
242 & 2275 & 630 & 676 & 2 \\
245 & 4857 & 380 & 396 & 4.5 \\
248 & 4994 & 130 & 434 & 3 \\
249 & 2088 & 140 & 412 & 4 \\
\hline
\end{tabular}


composition to low-K abyssal tholeiites (Erlank and Reid, this volume). From the biostragraphic information (Schlich et al., Chapter 2, this volume), the basaltic basement is dated as pre-late Campanian ( 71 to $73 \mathrm{~m} . \mathrm{y}$.). This age is in very good agreement with the 72 m.y. magnetic age derived from identified magnetic anomalies on, and near, Site 239 (Schlich, Chapter 30, this volume). No radiometric age dates are available at present for the basalt recovered at this site.

At Site 245 , the basaltic basement was reached 389 meters below the sea floor and cored between 389 and 396.5 meters subbottom depth with 1.6 meter recovery (Cores 17, 18, and 19). The basalt which first appears in Core 17 is dark gray, with a glassy to fine-grained texture. Cores 18 and 19 contain gray, medium-grained, extremely fresh appearing diabasic basalt which has a similar composition to the low-K tholeiites of oceanic ridges (Erlank and Reid, this volume). The lowest sediments cored, about 7.5 meters above the basaltic basement, were dated as early Paleocene, 61 to 63 m.y., (Schlich et al., Chapter 7, this volume). From the magnetic anomalies identified, the oceanic crust at Site 245 is dated at 69.5 m.y. (Schlich, Chapter 30, this volume). This age, which, taking into account the lack of recovery (about $7.5 \mathrm{~m}$ ) in the last core, is about 7 percent older than the age derived from the oldest sediments recovered. McKee (this volume) dated the diabasic basalt by the $\mathrm{K} / \mathrm{Ar}$ method and found an age of $27 \pm 3$ m.y., thereby establishing its intrusive origin and the possibility of older sediments occurring deeper in the hole.

Basalt at Site 248 was recovered between 422 and 434 meters subbottom depth in Cores 15, 16, and 17 (total recovery: $3.6 \mathrm{~m}$ ). The basalt is porphyritic with large prismatic phenocrysts of plagioclase, but the ground mass texture changes progressively from glassy to diabasic from the top down to the bottom of the cored interval. Compared to the other basalts recovered, the Site 248 samples show distinctive trace element compositions which led Erlank and Reid (this volume) to suggest that these basalts are chemically similar to the Karroo lavas from the Lebombo region. The basal sediments were not recovered, and the age of the oldest sediment is dated as early Eocene or possibly late Paleocene, about 55 m.y., (Schlich et al., Chapter 9, this volume). McKee (this volume) dated the basalt by the $\mathrm{K} / \mathrm{Ar}$ method in Core 15 as $72 \pm 7$ m.y. There is a large discrepancy between the age of basalt and the age of the oldest sediment which might possibly be explained by a Late Cretaceous-late Paleocene hiatus or by the existence of a condensed sequence of Paleocene and Cretaceous sediments in the lowermost 6 meters of sediment that was not recovered.

At Site 249, the hole penetrated 408 meters of sediments and 4 meters into the underlying basaltic basement (3.1 m recovery in Core 33$)$. The uppermost part of this basalt core is glassy, highly vesicular, and deeply weathered, while the lower portion $(33, \mathrm{CC})$ appears more massive and crystalline. According to Erlank and Reid (this volume), these basalts are also similar in composition to the low-K tholeiites recovered from mid-oceanic ridges. From the biostratigraphic information, the age of these basalts is established as pre-late Neocomian (130/140 m.y.).

\section{PROCEDURES}

The intensities $(J)$ and directions ( $I$, " $D$ ") of the remanent magnetization were measured before cutting each of the nine samples listed in Table I. The viscous remanent magnetization $(K v)$ was also estimated for each sample. A slab of about $0.4 \mathrm{~cm}$ thickness was cut from samples 239-21-1, 12-18 cm (No. 1); 245-19-1, 82-85 cm; 248-17, BHA; and 249-33, CC for radiometric dating. The results of these measurements are not yet available.

Paleomagnetic measurements were made on each of these $0.4 \mathrm{~cm}$ slabs and on the remainder of the sample in order to evaluate the sawing effect. Except for two samples, $245-19-1,82-85 \mathrm{~cm}$ and $248-17-1,140-144 \mathrm{~cm}$, which have been kept as "archive", a slab of $4.0 \mathrm{~cm}$ thickness was cut from the other samples listed in Table 1 . These slabs were then cut, for further paleomagnetic measurements, according to the scheme given in Figure 1. For this study, only parts numbered 3,5 , and 6 of each of these $4.0 \mathrm{~cm}$ slabs were used. On part number 5 , which has no simple
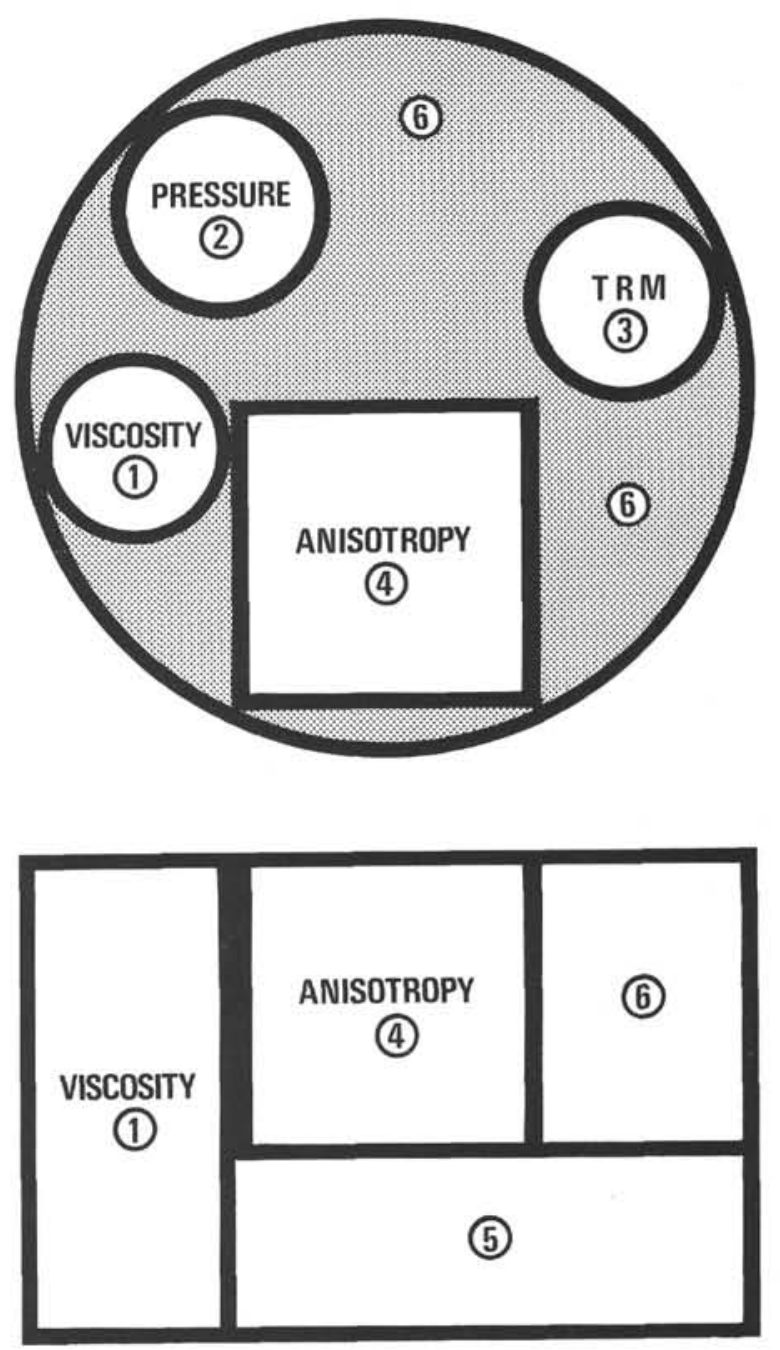

\section{CUTTING OF PALEOMAGNETIC SAMPLE}

Figure 1. Cutting of DSDP Leg 25 paleomagnetic samples. 
geometric shape, alternating magnetic field and thermal demagnetization studies were performed. On part number 3 , which is a cylinder of $0.8 \mathrm{~cm}$ radius and $2.5 \mathrm{~cm}$ thickness, thermal remanent magnetization (TRM) and susceptibility (k) studies were conducted. Curie temperatures $(T c)$ were also estimated from these samples. The intensity of saturation isothermal remanent magnetization ( $\sigma r)$, the remanent coercivity $(\mathrm{Hcr})$; and the induced saturation magnetization $(\sigma i)$ were measured on part number 6 of each slab.

\section{PALEOMAGNETIC MEASUREMENTS AND RESULTS}

The first shore-based measurements done prior to cutting the samples listed in Table I were made with a $5-\mathrm{Hz}$ spinner magnetometer (Thellier 1967). Variation of intensities $(J)$ and directions $(I$, " $D$ ") of the remanent magnetization during alternating magnetic field and thermal demagnetization were measured with an astatic magnetometer (Pozzi and Thellier, 1963).

\section{Initial Measurements and Magnetic Viscosity}

The results of the initial intensities and directions of the remanent magnetization are given in Table 3. The samples from Sites 239 and 245 appear to have reversed magnetization. This will be discussed in the following section. The magnetic viscosity was estimated from measurements made after holding the specimens in the direction of the earth's magnetic field for a 15 day period and then in the opposite direction for the same time interval. The "stable" natural remanent magnetization (NRM) is given in Table 3, and the last column refers to the coefficient of viscosity $(K v)$. The samples of Site 245 present a high value of magnetic viscosity of about 17 percent in contrast to the results obtained for Site 249 , for which the viscosity can be neglected. For Sites 239 and 248 the coefficient of viscosity ranges between 2 and 8 percent.

Initial measurements made on the small $0.4-\mathrm{cm}$-thick slabs and on the remainder of the samples have proven the importance of sawing effects. For Sites 239 and 249, changes of only $1^{\circ}$ in inclination and about 15 percent in intensity of remanent magnetization were observed. For Site 245 , the changes in inclination are as large as $16^{\circ}$ and the intensity changes are about 20 percent of the initial value. In some circumstances, it was even possible to observe a complete reversal of the magnetization in Site 245 samples due to sawing. This superimposed magnetization decreased by a factor of about 25 percent in 15 days and appeared to vanish in an alternating magnetic field of $1500 \mathrm{e}$, which, as will be shown later, also affects the natural remanent magnetization.

\section{Alternating Magnetic Field and Thermal Demagnetization}

Each sample was subjected to stepwise partial alternating field demagnetization up to a field value of 600 Oe. The variations of intensity are shown in Figures 2 and 3 for the seven selected samples. Stereographic projections of the remanent directions during this demagnetization process are given in Figures 4 and 5. The basalt samples of Sites 239 and 249 are characterized by a relative "hard" magnetization and a stable magnetic direction compared to

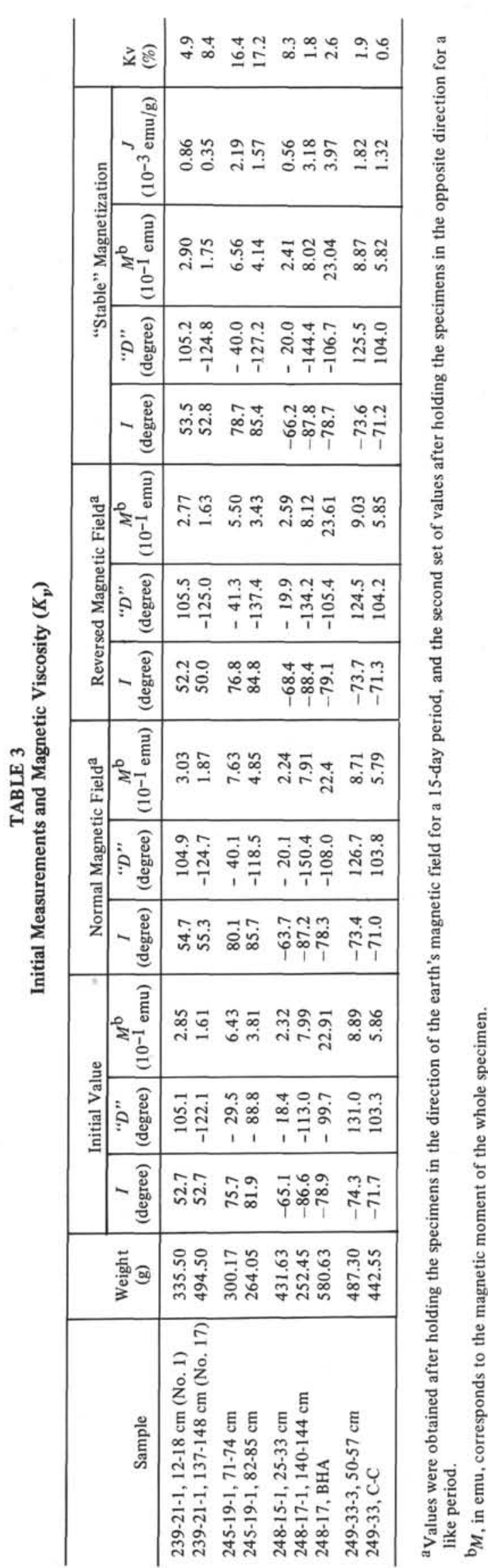



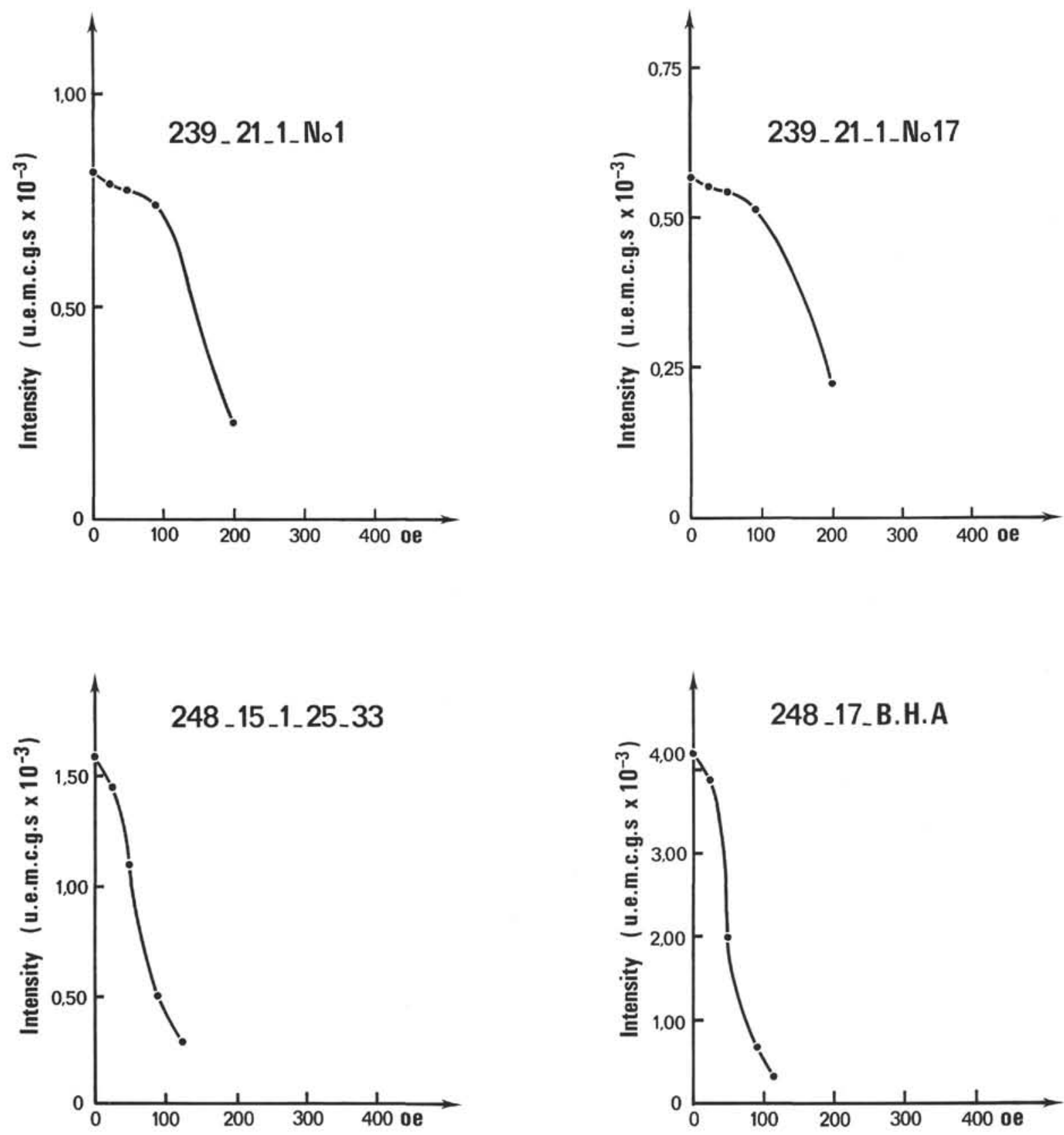

\section{PEAKS DEMAgNetizing Field (oe.)}

Figure 2. Variation of intensity of remanence during alternating field demagnetization of samples from Sites 239 and 248 .

the samples of Site 245 , and also to a certain extent, those of Site 248. Thus, in an alternating field of $100 \mathrm{Oe}$, the magnetization of the basalt from Site 245 is only 4 percent of the initial value, whereas in the same alternating field the magnetization of the basalt of Site 249 is still 85 percent of the initial value. Moreover, the shape of the curves of Figures 2 and 3 suggests for the samples of Sites 239 and 249 a thermal remanent magnetization (TRM).

For Site 245, and possibly for Site 248 , the magnetization could be interpreted as an isothermal remanent magnetization (IRM). The results of direction and intensity measurements during the alternating field demagnetization process are summarized in Table 4. A mean value for direction has been calculated for the samples from Sites 239 and 249; the values obtained for the inclination are very consistent at each site:

Sample 239-21-1, $12-18 \mathrm{~cm}$ (no. 1$): I=+45.0^{\circ}$

Sample 239-21-1,137-148 cm (no. 17): $I=+44.6^{\circ}$

Sample 249-33, $50-57 \mathrm{~cm}: I=-66.9^{\circ}$

Sample 249-33, CC: $I=-69.4^{\circ}$

For Site 248 , a direct comparison of the results obtained for the two samples was not possible since only Sample 248-17, BHA shows a stable magnetization. However, it is remarkable to observe that the final value of $-65.1^{\circ}$ 

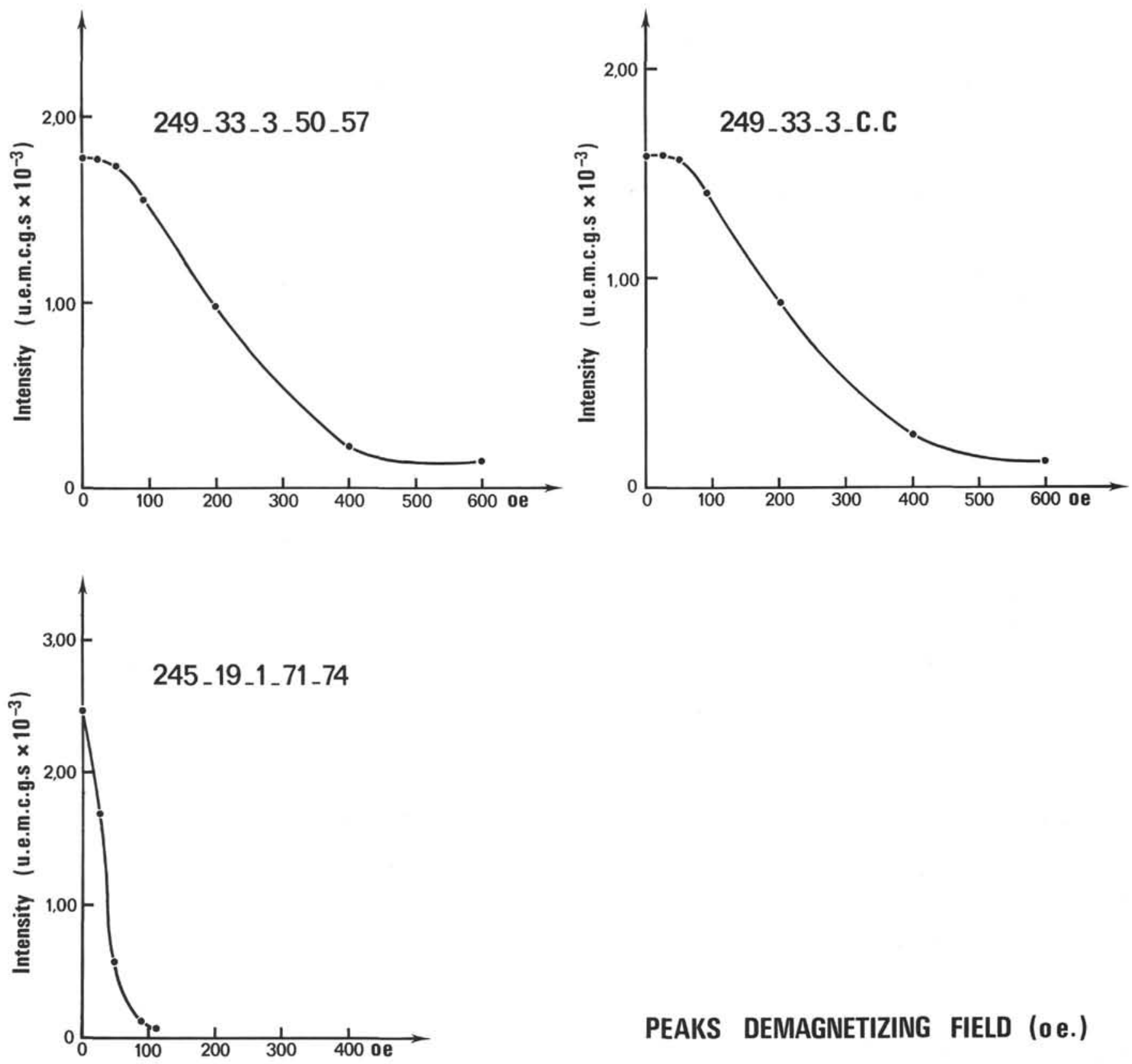

PEAKS DEMAgNetizing FIELD (o e.)

Figure 3. Variation of intensity of remanence during alternating field demagnetization of samples from Sites 245 and 249.

observed for Sample 248-15-1, 25-33 cm after 125 Oe is similar to the mean stable value of $-63.2^{\circ}$ calculated for Sample 248-17, BHA.

The samples were also subjected to stepwise partial thermal demagnetization up to a temperature of about $550^{\circ} \mathrm{C}$. The variations in intensity are shown in Figures 6 and 7. Stereographic projections of the remanent directions during this thermal demagnetization process are presented in Figures 8 and 9. The results (Table 5) are in complete agreement with the conclusions given above for alternating field demagnetization process. Samples from Sites 239 and 249 appear very stable compared to those from Sites 245 and 248. The mean calculated values of the inclination are: Sample 239-21-1, 12-18 cm (No. 1): $+43.2^{\circ}$; Sample 239-21-1, 137-148 cm (No. 17): $+45.3^{\circ}$; Sample 249-33-3, 50-57 cm: $-72.5^{\circ}$; and Sample 249-33, CC:-73.9 . The particular shape of the intensity curve for Sample 248-15-1, $25-33 \mathrm{~cm}$ can be explained by the superposition of two different magnetizations. The large difference which exists between the initial values of magnetization for both samples, 248-15-1, 25-33 cm and 248-17, BHA, favors this interpretation.

Thermal Remanent Magnetization, Susceptibility, and Curie Temperature

Thermal remanent magnetization studies were conducted following the method of double heating proposed by Thellier and Thellier (1959). The susceptibility $(k)$ and the Curie temperature $(T c)$ were also obtained from these measurements. Results of the thermal remanent magnetization studies for Samples 239-21-1, 12-18 cm (No. 1); 249-33, CC; and 249-33-3, 50-57 cm are given in Figures 
- Initial value.

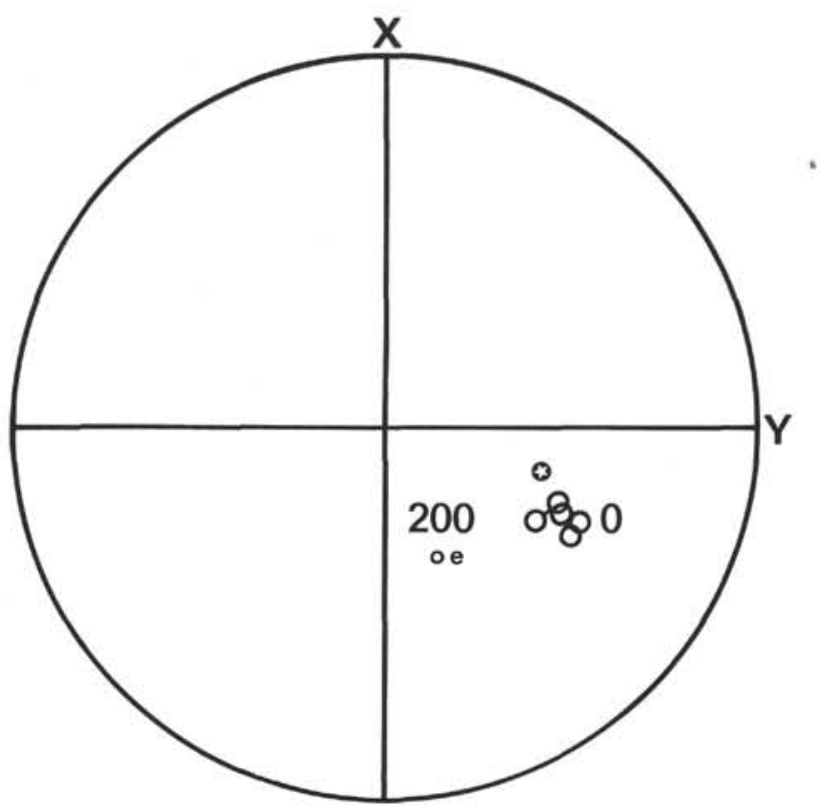

SAMPLE 239_21_1_No1

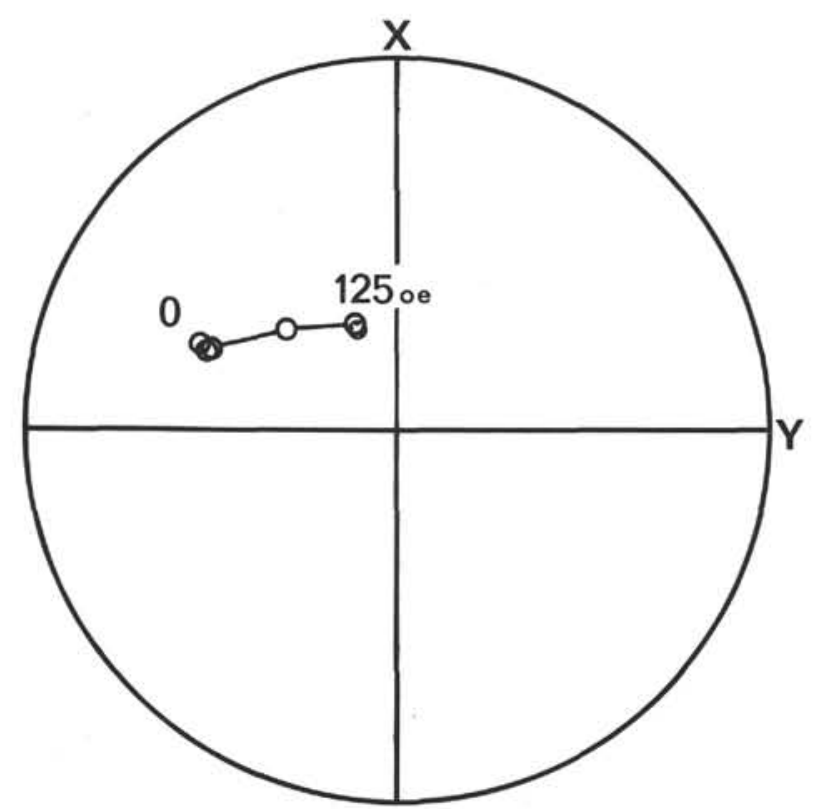

SAMPLE 248_15_1_25_33

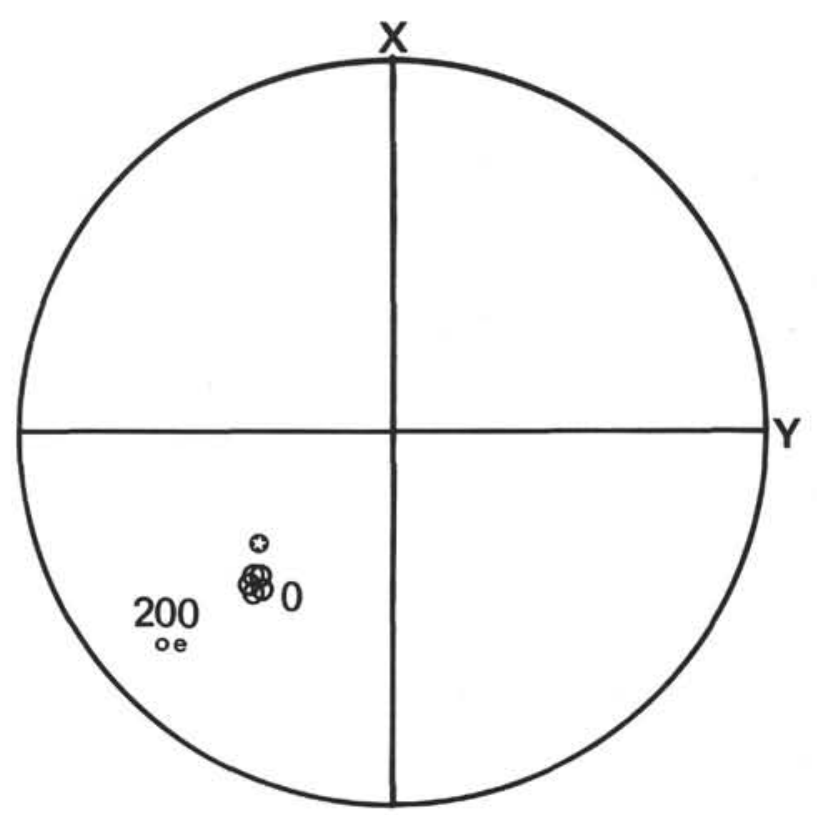

SAMPLE 239_21_1_No17

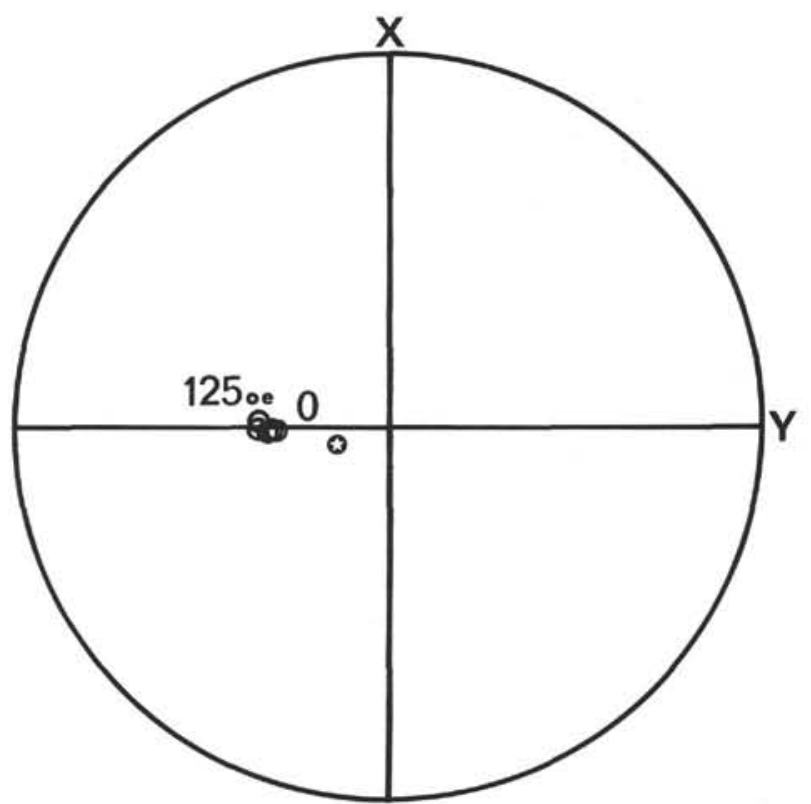

SAMPLE 248_17_B.H.A

Figure 4. Variation of direction of remanence during alternating field demagnetization of samples from Sites 239 and 248.

10 and 11. The TRM curves correspond to the thermal remanent magnetization acquired during cooling of the sample from the temperature $(T)$ to the ambient temperature in a magnetic field of $0.5 \mathrm{Oe}$. The NRM curves correspond to the natural remanent magnetization left after heating the sample at temperature $(T)$ and cooling it in a zero magnetic field. These curves indicate that the samples have undergone mineralogical changes during the laboratory heating.
Figures 12 and 13 show the variation of susceptibility with temperature for six of the selected samples. The measurements were done at different temperatures up to about $600^{\circ} \mathrm{C}$, and each of these determinations was followed by a measurement at $20^{\circ} \mathrm{C}$. The suspected mineralogical changes are clearly confirmed by the variability of the values obtained at $20^{\circ} \mathrm{C}$. The samples from Site 239 however, show a relative mineralogical stability between $20^{\circ} \mathrm{C}$ and $200^{\circ} \mathrm{C}$ (Figure 12). The Curie 


\section{- Initial value.}

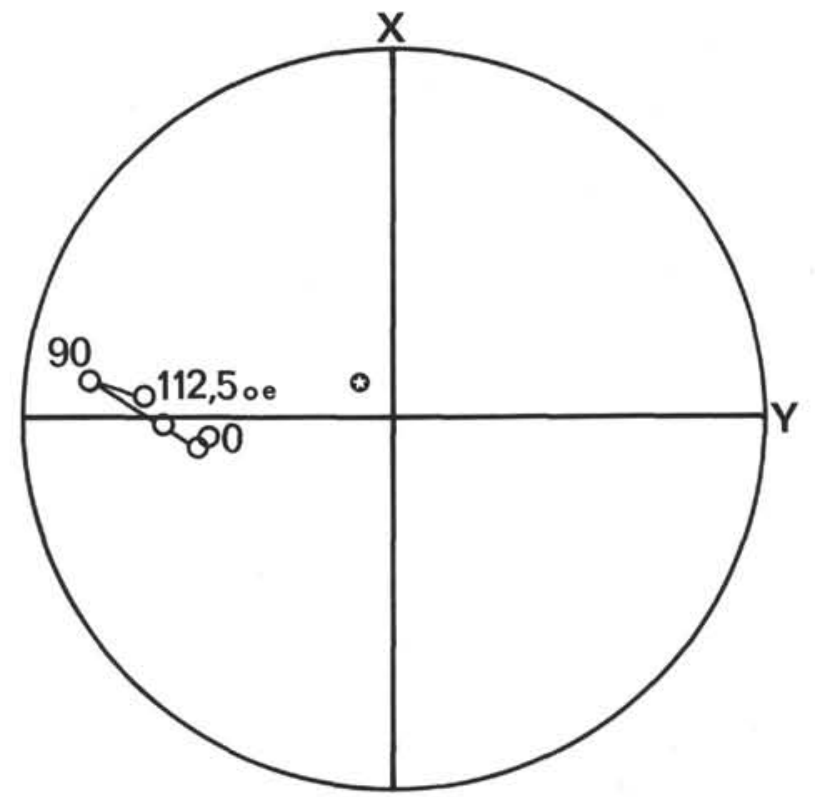

SAMPLE 245_19_1_71_74

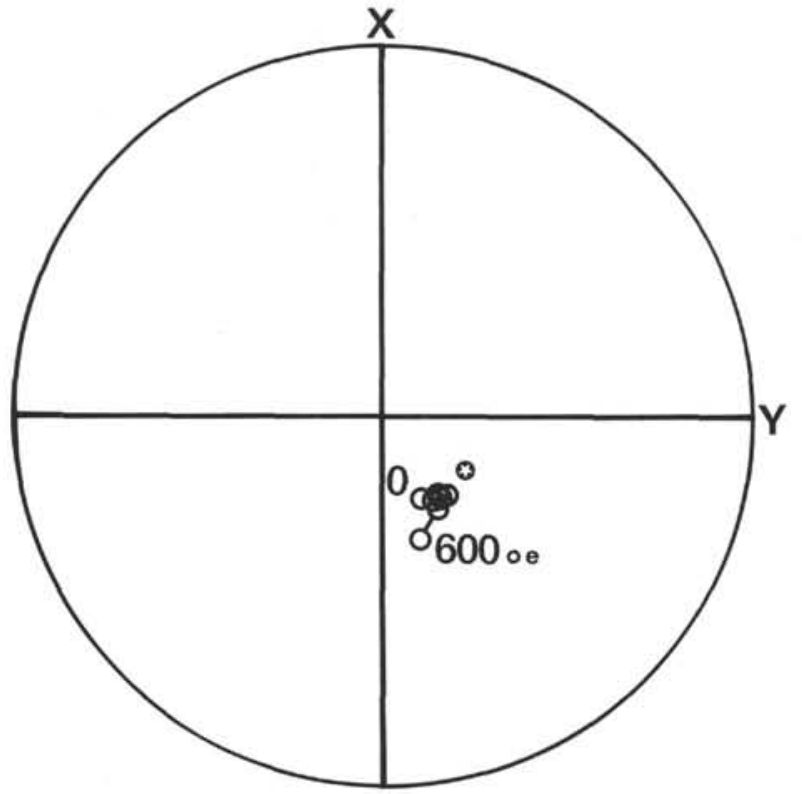

SAMPLE 249_33_3_50_57

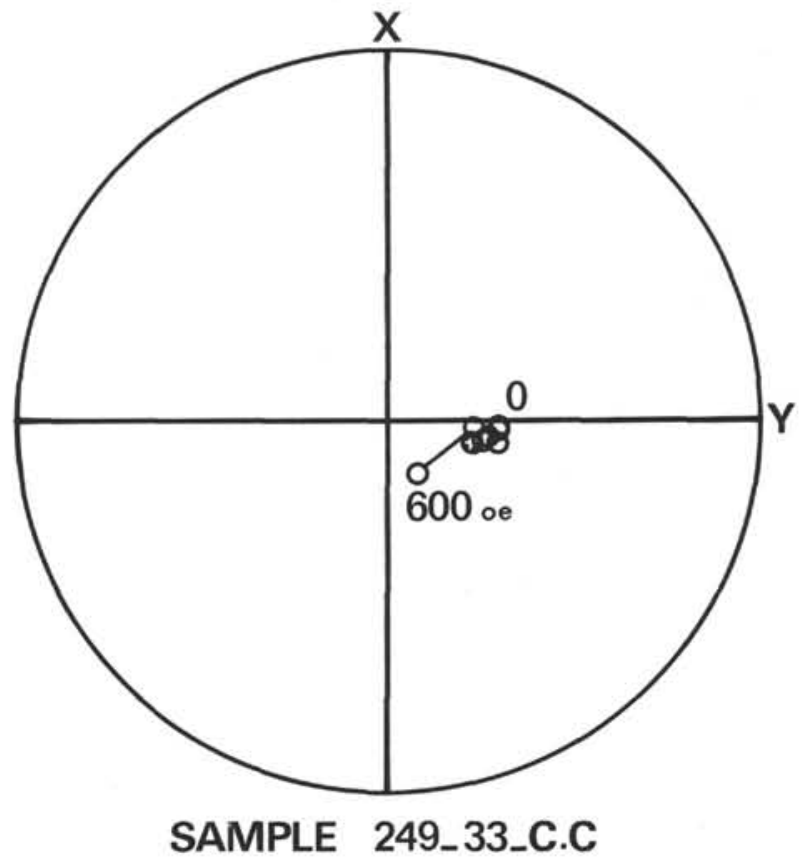

SAMPLE 249_33_C.C

Figure 5. Variation of direction of remanence during alternating field demagnetization of samples from Sites 245 and 249.

temperature analyses are presented in Figures 14 and 15 for the seven selected samples. The shape of these curves associated to the known mineralogical instability, suggest, in fact, much lower Curie temperatures than the values which can be derived from the different curves.

\section{CONCLUSION}

Principal results of the paleomagnetic studies on igneous samples from Leg 25 are summarized in Table 6. The inclinations $(I)$ given in this table correspond to the mean values calculated for each sample from the results of the alternating magnetic field and thermal demagnetization process. The intensities of remanent magnetization $(J)$ are "stable" values calculated by taking into account the magnetic viscosity. The induced saturation magnetization $(\sigma i)$, the intensity of saturation isothermal remanent magnetization $(\sigma r)$, and the remanent coercivity $(\mathrm{Hcr})$ are also given for each sample. The magnetic susceptibility $(k)$ is given for a temperature of $20^{\circ} \mathrm{C}$, and the probable Curie 
TABLE 4

Direction and Intensity of Remanent Magnetization During Alternating Field Demagnetization Process

\begin{tabular}{|c|c|c|c|c|c|c|c|c|}
\hline $\begin{array}{l}\text { Alternating } \\
\text { Field } \\
\text { (Oe) }\end{array}$ & $\begin{array}{l}\text { Sample } \\
\begin{array}{l}\text { Directions } \\
\text { Intensity }\end{array}\end{array}$ & $\begin{array}{c}239 \\
21-1,12-18 \mathrm{~cm} \text { (No. } 1)\end{array}$ & $\begin{array}{c}239 \\
21-1,137-148 \mathrm{~cm} \text { (No. 17) }\end{array}$ & $\begin{array}{c}245 \\
19-1,71-74 \mathrm{~cm}\end{array}$ & $\begin{array}{c}248 \\
15-1,25-33 \mathrm{~cm}\end{array}$ & $\begin{array}{c}248 \\
17, \text { BHA }\end{array}$ & $\begin{array}{c}249 \\
33-3,50-57 \mathrm{~cm}\end{array}$ & $\begin{array}{c}249 \\
33, \mathrm{CC}\end{array}$ \\
\hline 0 & $\begin{array}{l}I \\
\text { "D” } \\
J\end{array}$ & $\begin{array}{r}40.5 \\
116.6 \\
0.81\end{array}$ & $\begin{array}{r}44.7 \\
-139.6 \\
0.57\end{array}$ & $\begin{array}{c}-49.0 \\
-95.5 \\
2.46\end{array}$ & $\begin{array}{r}-42.0 \\
-66.9 \\
1.58\end{array}$ & $\begin{array}{r}-65.4 \\
-92.2 \\
4.20\end{array}$ & $\begin{array}{r}-70.2 \\
154.5 \\
1.82\end{array}$ & $\begin{array}{c}-65.8 \\
95.9 \\
1.61\end{array}$ \\
\hline 25 & $\begin{array}{l}I \\
\text { "D" } \\
J\end{array}$ & $\begin{array}{c}41.1 \\
120.5 \\
0.78\end{array}$ & $\begin{array}{r}46.3 \\
-137.1 \\
0.55\end{array}$ & $\begin{array}{c}45.7 \\
-97.7 \\
1.68\end{array}$ & $\begin{array}{r}-44.2 \\
-68.0 \\
1.44\end{array}$ & $\begin{array}{r}-64.4 \\
-92.4 \\
3.86\end{array}$ & $\begin{array}{r}-69.8 \\
147.8 \\
1.82\end{array}$ & $\begin{array}{c}-65.6 \\
94.5 \\
1.62\end{array}$ \\
\hline 50 & $\begin{array}{l}I \\
\text { "D" } \\
J\end{array}$ & $\begin{array}{c}45.4 \\
116.7 \\
0.77\end{array}$ & $\begin{array}{r}45.3 \\
-136.2 \\
0.54\end{array}$ & $\begin{array}{r}37.4 \\
-91.6 \\
0.57\end{array}$ & $\begin{array}{r}-44.7 \\
-67.5 \\
1.08\end{array}$ & $\begin{array}{r}-63.8 \\
-92.4 \\
2.01\end{array}$ & $\begin{array}{r}-68.7 \\
141.6 \\
1.78\end{array}$ & $\begin{array}{c}-65.8 \\
101.6 \\
1.57\end{array}$ \\
\hline 90 & $\begin{array}{l}I \\
\text { "D" } \\
J\end{array}$ & $\begin{array}{c}47.7 \\
114.3 \\
0.73\end{array}$ & $\begin{array}{r}43.7 \\
-135.6 \\
0.51\end{array}$ & $\begin{array}{r}15.7 \\
-80.5 \\
0.13\end{array}$ & $\begin{array}{r}-57.1 \\
-47.9 \\
0.50\end{array}$ & $\begin{array}{c}-61.4 \\
-87.1 \\
0.72\end{array}$ & $\begin{array}{r}-70.0 \\
144.8 \\
1.59\end{array}$ & $\begin{array}{c}-67.8 \\
99.7 \\
1.43\end{array}$ \\
\hline 112.5 & $\begin{array}{l}I \\
\text { "D" } \\
J\end{array}$ & & & $\begin{array}{r}33.8 \\
-85.1 \\
0.07\end{array}$ & & $\begin{array}{r}-60.9 \\
-91.8 \\
0.32\end{array}$ & & \\
\hline 125 & $\begin{array}{l}I \\
\text { “D” } \\
J\end{array}$ & & & & $\begin{array}{r}-65.1 \\
-22.0 \\
0.28\end{array}$ & & & \\
\hline 200 & $\begin{array}{l}I \\
\text { “D” } \\
J\end{array}$ & $\begin{array}{c}50.1 \\
123.2 \\
0.22\end{array}$ & $\begin{array}{r}42.9 \\
-139.0 \\
0.22\end{array}$ & & & & $\begin{array}{r}-69.2 \\
144.1 \\
1.00\end{array}$ & $\begin{array}{c}-69.0 \\
101.9 \\
0.89\end{array}$ \\
\hline 400 & $\begin{array}{l}I \\
\text { “D” } \\
J\end{array}$ & & & & & & $\begin{array}{r}-68.0 \\
149.3 \\
0.33\end{array}$ & $\begin{array}{c}-70.9 \\
95.9 \\
0.25\end{array}$ \\
\hline 600 & $\begin{array}{l}I \\
\text { " } D " \\
J\end{array}$ & & & & & & $\begin{array}{r}-62.6 \\
163.1 \\
0.16\end{array}$ & $\begin{array}{c}-76.5 \\
150.3 \\
0.12\end{array}$ \\
\hline Weight (g) & & 26.4 & 23.6 & 22.2 & 41.1 & 31.6 & 41.2 & 36.9 \\
\hline
\end{tabular}

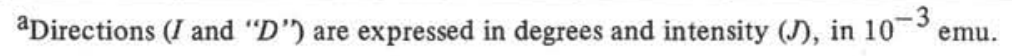



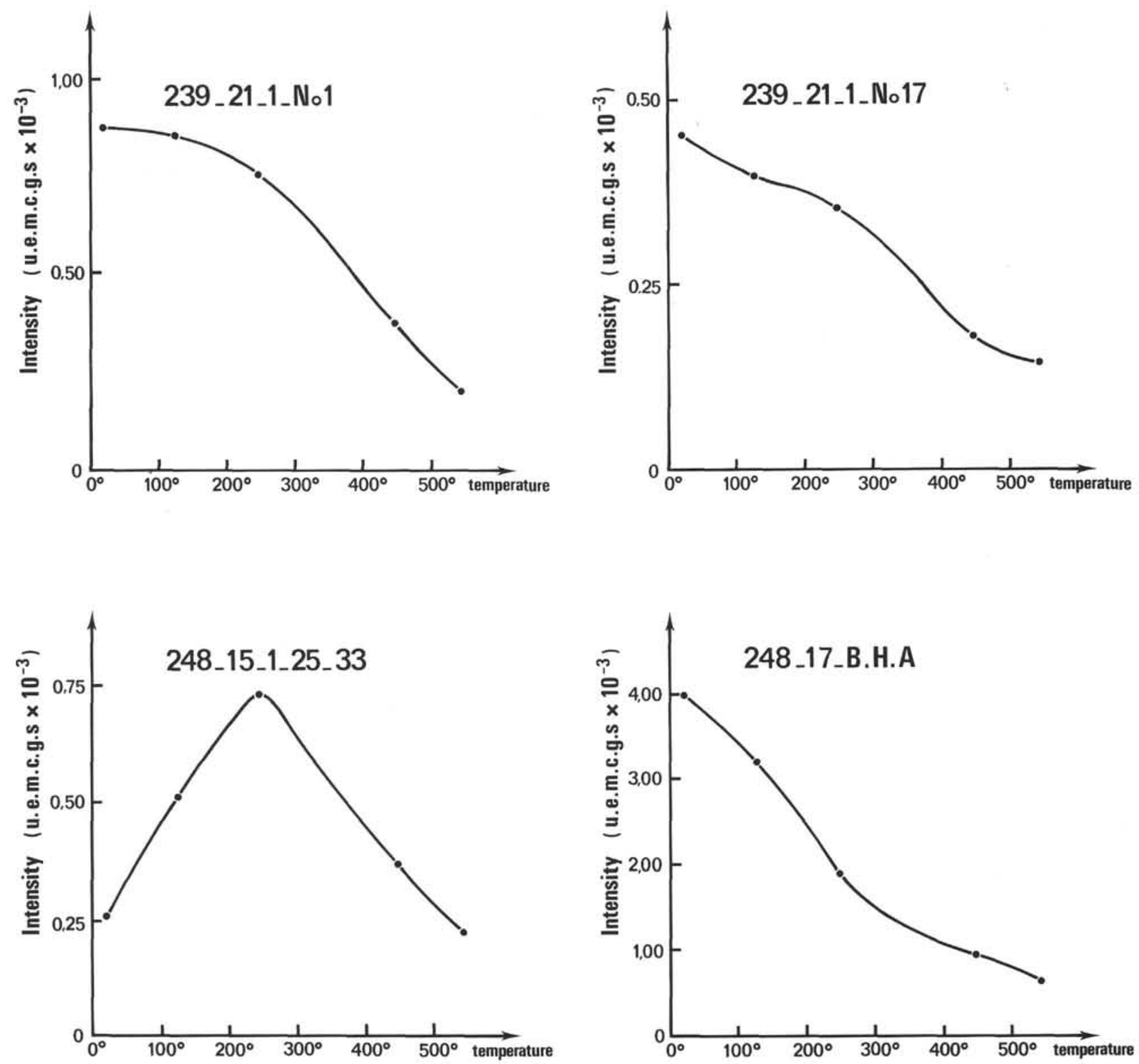

\section{THERMAL DEMAGNETIZATION}

Figure 6. Variation of intensity of remanence during thermal demagnetization of samples from Sites 239 and 248.

temperatures have been estimated from the experimental curves given in Figures 14 and 15. In the last column of Table 6, a mean paleolatitude has been calculated for Sites 239,248 , and 249 , assuming a steady dipole magnetic field configuration. The intensities and directions ( $I$ only) are well defined for samples of Sites 239 and 249. The samples of Site 248 , and particularly of Site 245 , are too unstable for paleomagnetic interpretations.

Late Cretaceous magnetic anomalies have been observed and identified in the Mascarene Basin (Schlich, this volume). The shape and amplitude of these anomalies suggest that the oceanic crust close to Site 239 was created between $20^{\circ} \mathrm{S}$ and $30^{\circ} \mathrm{S}$. This interpretation is in good agreement with the calculated paleolatitude $\left(26^{\circ} \mathrm{S}\right)$ of Site 239.
It is necessary here to stress the importance of sawing effect, which in some circumstances, and particularly for small samples bearing "soft" magnetization, may destroy completely the initial magnetization. Moreover, it has been proven that the heating of samples introduces severe mineralogical changes.

\section{ACKNOWLEDGMENTS}

We would like to thank T. Vallier who obtained the specimens used by us in this study. We also thank professor E. Thellier for his advice and the technical facilities provided by his paleomagnetic laboratory. We are greatly indebted to M. Le Goff who participated in the paleomagnetic measurements. This work was supported by Institut de Physique du Globe de Paris (University of Paris 
TABLE 5

Direction and Intensity of Remanent Magnetization During Thermal Demagnetization Process

\begin{tabular}{|c|c|c|c|c|c|c|c|c|}
\hline $\begin{array}{l}\text { Temperature } \\
\left({ }^{\circ} \mathrm{C}\right)\end{array}$ & $\begin{array}{l}\text { Sample } \\
\text { Directions, } \\
\text { Intensity }^{\mathrm{a}}\end{array}$ & $\stackrel{239}{21-1,12-18 \mathrm{~cm} \text { (No. 1) }}$ & $\begin{array}{c}239 \\
21-1,137-148 \mathrm{~cm} \text { (No. 17) }\end{array}$ & $\begin{array}{c}245 \\
19-1,71-74 \\
\mathrm{~cm}\end{array}$ & $\begin{array}{c}248 \\
15-1,25-33 \\
\mathrm{~cm}\end{array}$ & $\begin{array}{c}248 \\
17, \mathrm{BHA}\end{array}$ & $\begin{array}{c}249 \\
33-3,50-57 \mathrm{~cm}\end{array}$ & $\begin{array}{l}249 \\
33, \mathrm{CC}\end{array}$ \\
\hline 20 & $\begin{array}{l}I \\
\text { "D } \\
J\end{array}$ & $\begin{array}{c}43.9 \\
119.9 \\
0.87\end{array}$ & $\begin{array}{r}53.1 \\
-145.3 \\
0.44\end{array}$ & $\begin{array}{r}58.0 \\
-175.5 \\
1.06\end{array}$ & $\begin{array}{c}-71.9 \\
130.9 \\
0.25\end{array}$ & $\begin{array}{r}-87.8 \\
153.0 \\
3.99\end{array}$ & $\begin{array}{r}-72.2 \\
118.4 \\
2.44\end{array}$ & $\begin{array}{c}-73.9 \\
111.3 \\
1.28\end{array}$ \\
\hline 126 & $\begin{array}{l}I \\
\text { "D" } \\
J\end{array}$ & $\begin{array}{r}44.4 \\
113.6 \\
0.85\end{array}$ & $\begin{array}{r}53.3 \\
-140.7 \\
0.39\end{array}$ & $\begin{array}{r}57.4 \\
-173.4 \\
0.85\end{array}$ & $\begin{array}{r}-72.3 \\
60.7 \\
0.51\end{array}$ & $\begin{array}{r}-88.6 \\
168.1 \\
3.19\end{array}$ & $\begin{array}{r}-72.2 \\
117.2 \\
2.47\end{array}$ & $\begin{array}{r}-74.4 \\
102.9 \\
1.28\end{array}$ \\
\hline 249 & $\begin{array}{c}I \\
\text { "D" } \\
J\end{array}$ & $\begin{array}{c}44.7 \\
115.9 \\
0.75\end{array}$ & $\begin{array}{c}47.6 \\
-141 \\
0.35\end{array}$ & $\begin{array}{r}47.5 \\
-151.8 \\
0.24\end{array}$ & $\begin{array}{c}-69.2 \\
44.7 \\
0.72\end{array}$ & $\begin{array}{r}-83.1 \\
-47.6 \\
1.89\end{array}$ & $\begin{array}{r}-72.7 \\
125.5 \\
2.34\end{array}$ & $\begin{array}{r}-74.1 \\
102.9 \\
1.19\end{array}$ \\
\hline 449 & $\begin{array}{l}I \\
\text { "D" } \\
J\end{array}$ & $\begin{array}{c}40.8 \\
122.1 \\
0.40\end{array}$ & $\begin{array}{r}36.4 \\
-140.8 \\
0.17\end{array}$ & $\begin{array}{r}11.1 \\
-152.9 \\
0.03\end{array}$ & $\begin{array}{r}-68.2 \\
39.2 \\
0.36\end{array}$ & $\begin{array}{r}-74.2 \\
-94.7 \\
0.94\end{array}$ & $\begin{array}{r}-72.6 \\
128.2 \\
0.81\end{array}$ & $\begin{array}{r}-73.2 \\
102.1 \\
0.35\end{array}$ \\
\hline 543 & $\begin{array}{l}I \\
\text { "D" } \\
J\end{array}$ & $\begin{array}{c}41.7 \\
126.3 \\
0.19\end{array}$ & $\begin{array}{r}36.0 \\
-140.5 \\
0.14\end{array}$ & $\begin{array}{c}30.2 \\
167.2 \\
0.05\end{array}$ & $\begin{array}{r}-64.6 \\
54.6 \\
0.21\end{array}$ & $\begin{array}{r}-74.0 \\
-101.6 \\
0.61\end{array}$ & $\begin{array}{c}-72.3 \\
132.6 \\
0.50\end{array}$ & $\begin{array}{r}-73.6 \\
114.7 \\
0.16\end{array}$ \\
\hline Weight (g) & & 29.9 & 21.6 & 18.4 & 30.1 & 31.3 & 31.3 & 34.6 \\
\hline
\end{tabular}

a Directions ( $I$ and " $D$ ") are expressed in degrees and intensity, $J$, in $10^{-3}$ emu.

TABLE 6

Principal Results of Paleomagnetic Studies on Igneous Samples, Leg 25

\begin{tabular}{|c|c|c|c|c|c|c|c|c|c|}
\hline \multicolumn{10}{|c|}{ NRM } \\
\hline Sample & $\begin{array}{c}I \\
\text { (degree) }\end{array}$ & $\left(10^{-3} \stackrel{J}{\mathrm{emu} / \mathrm{g})}\right.$ & $\begin{array}{l}K \nu \\
(\%)\end{array}$ & $\begin{array}{c}\sigma i \\
(\mathrm{emu} / \mathrm{g})\end{array}$ & $\left(10^{-1} \frac{\sigma r}{\mathrm{emu} / \mathrm{g}}\right)$ & $\begin{array}{l}\mathrm{Hcr} \\
(\mathrm{Oe})\end{array}$ & $\left(10^{-4} / \mathrm{cm}^{3}\right)$ & $\begin{array}{c}T c \\
\text { (degree) }\end{array}$ & $\begin{array}{l}\text { Latitude } \\
\left({ }^{\circ} \mathrm{S}\right)\end{array}$ \\
\hline $239-21-1,12-18 \mathrm{~cm}$ (No. 1) & 44 & 0.86 & 5 & 0.75 & 1.68 & 177 & 7.7 & $350\}$ & \multirow{2}{*}{26.2} \\
\hline $239-21-1,137-148 \mathrm{~cm}$ (No. 17 ) & 45 & 0.35 & 8 & 0.70 & 1.41 & 155 & 6.2 & $-\int$ & \\
\hline $245-19-1,71-74 \mathrm{~cm}$ & - & 2.19 & 16 & 1.54 & 1.01 & 28 & 28.3 & 250 & - \\
\hline $248-15-1,25-33 \mathrm{~cm}$ & -65 & 0.56 & 8 & 1.08 & 1.12 & 42 & 10.6 & - & - \\
\hline 248-17, BHA & -65 & 3.97 & 3 & 0.82 & 0.74 & 39 & 10.4 & 250 & $(44.7)$ \\
\hline $249-33-3,50-57 \mathrm{~cm}$ & -71 & 1.82 & 2 & 1.40 & 1.38 & 139 & 15.0 & $500\}$ & \multirow{2}{*}{56.1} \\
\hline $249-33, \mathrm{CC}$ & -72 & 1.32 & 1 & 1.28 & 1.09 & 178 & 10.1 & $500\}$ & \\
\hline
\end{tabular}



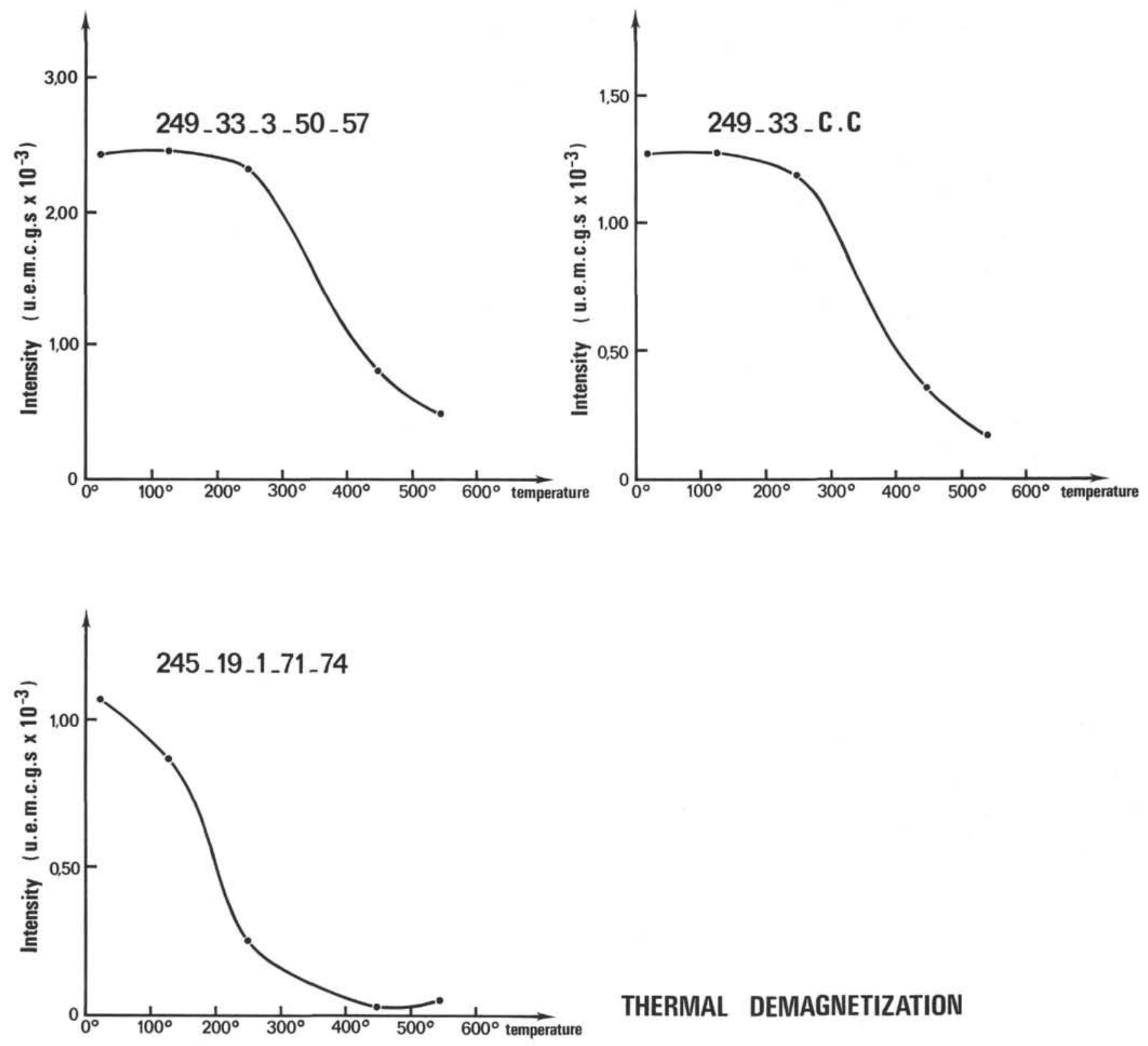

\section{THERMAL DEMAGNETIZATION}

Figure 7. Variation of intensity of remanence during thermal demagnetization of samples from Sites 245 and 249.

VI), Centre National de la Recherche Scientifique, and the National Science Foundation.

\section{REFERENCES}

Pozzi, J. P. and Thellier, E., 1963. Sur les perfectionnements récents apportés aux magnétomètres à très haute sensibilité utilisés en minéralogie et en paléomagnétisme: Compt: Rendus Acad. Sci. Paris, v. 257 , p. 1037-1040.

Thellier, E., 1967. A big sample spinner magnetometer. In Methods in paleomagnetism: New York, Amsterdam (Elsevier Publishing Co.) p. 149-154.

Thellier, E. and Thellier, O., 1959. Sur l'intensité du champ magnétique terrestre dans le passé historique et géologique: Ann. Géophys., v. 15, p. 285-376. 
- Initial value.
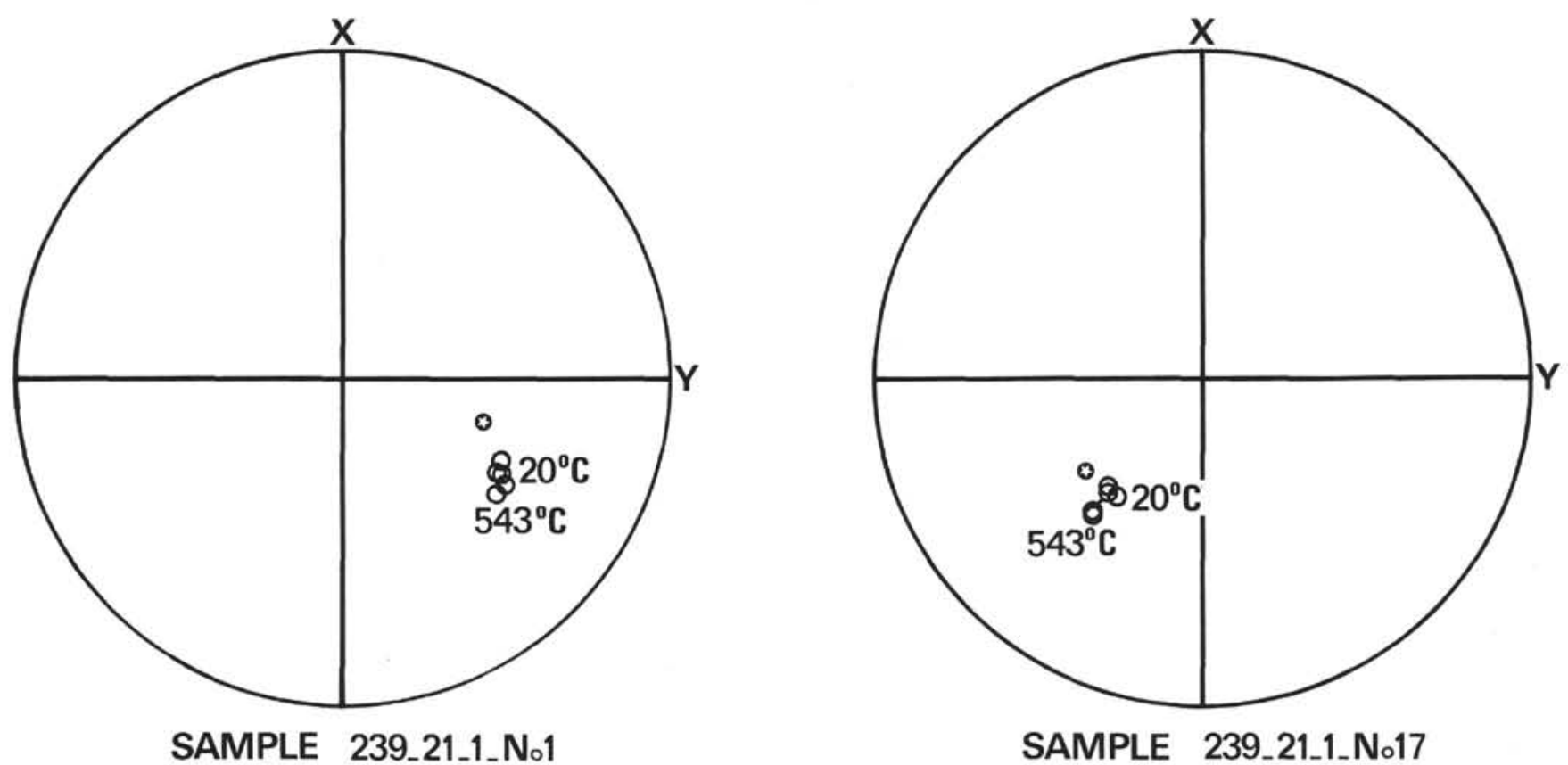

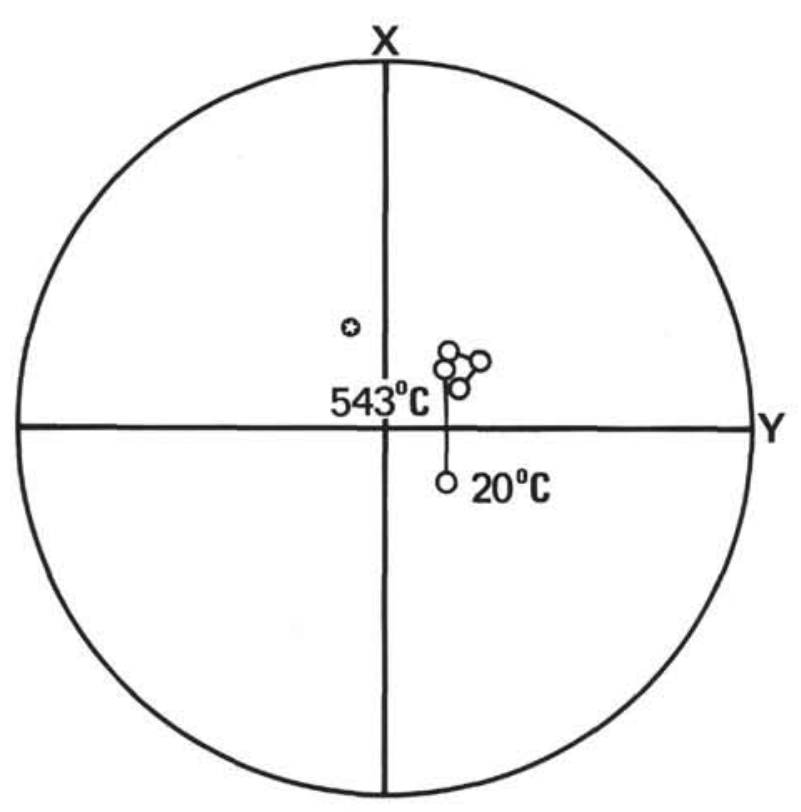

SAMPLE 248_15_1_25_33

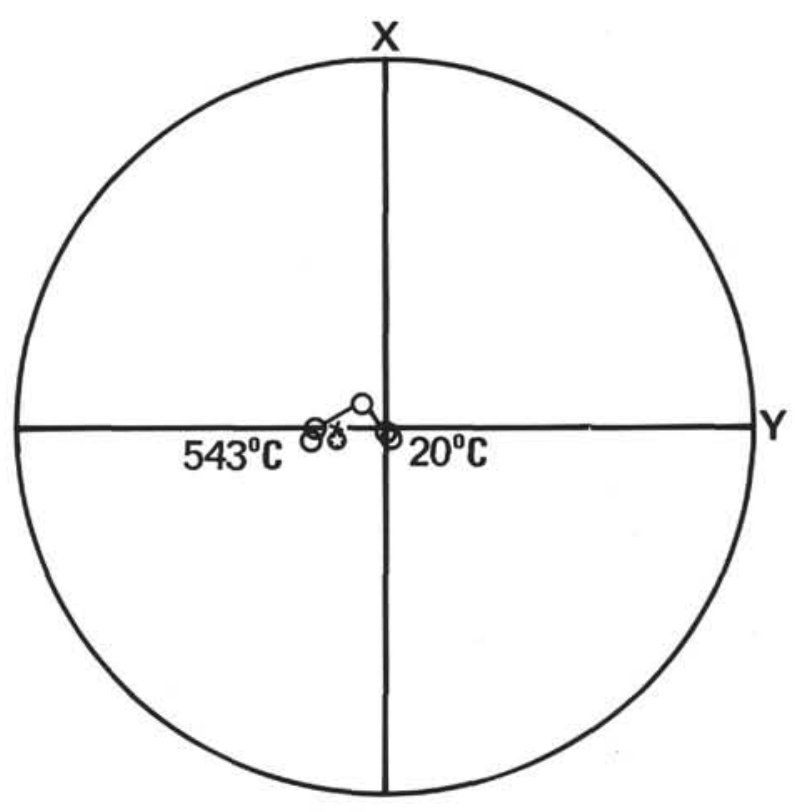

SAMPLE 248_17_B.H.A

Figure 8. Variation of direction of remanence during thermal demagnetization of samples from Sites 239 and 248. 
- Initial value.

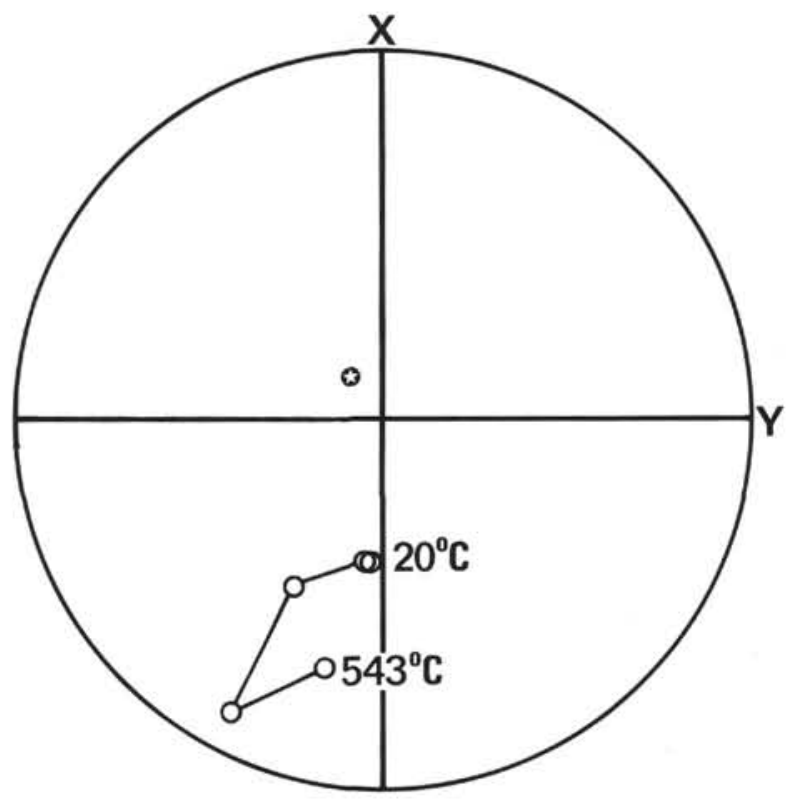

SAMPLE 245_19_1_71_74

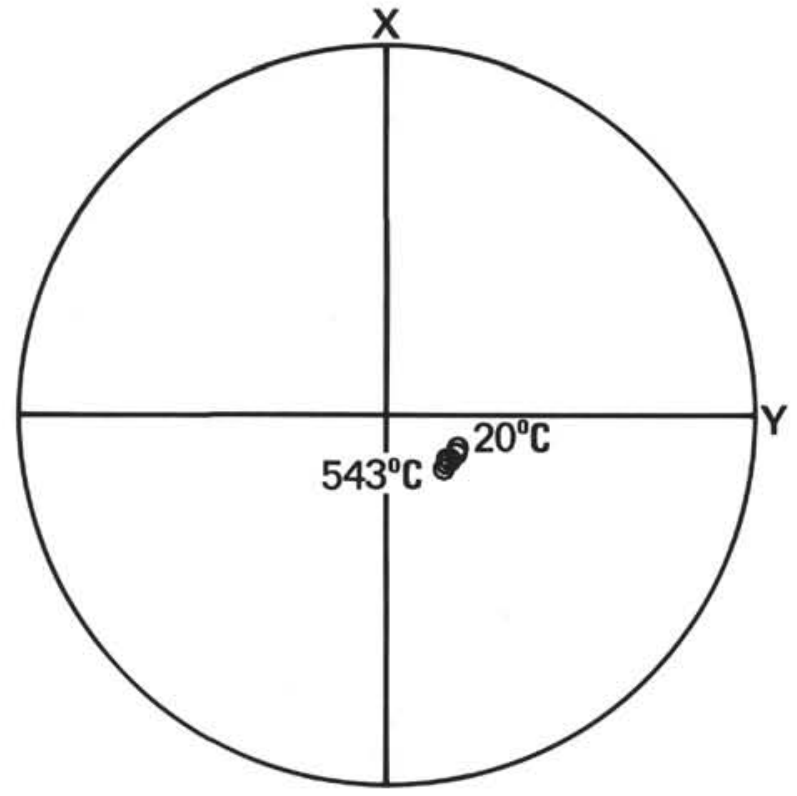

SAMPLE 249_33_3_50-57

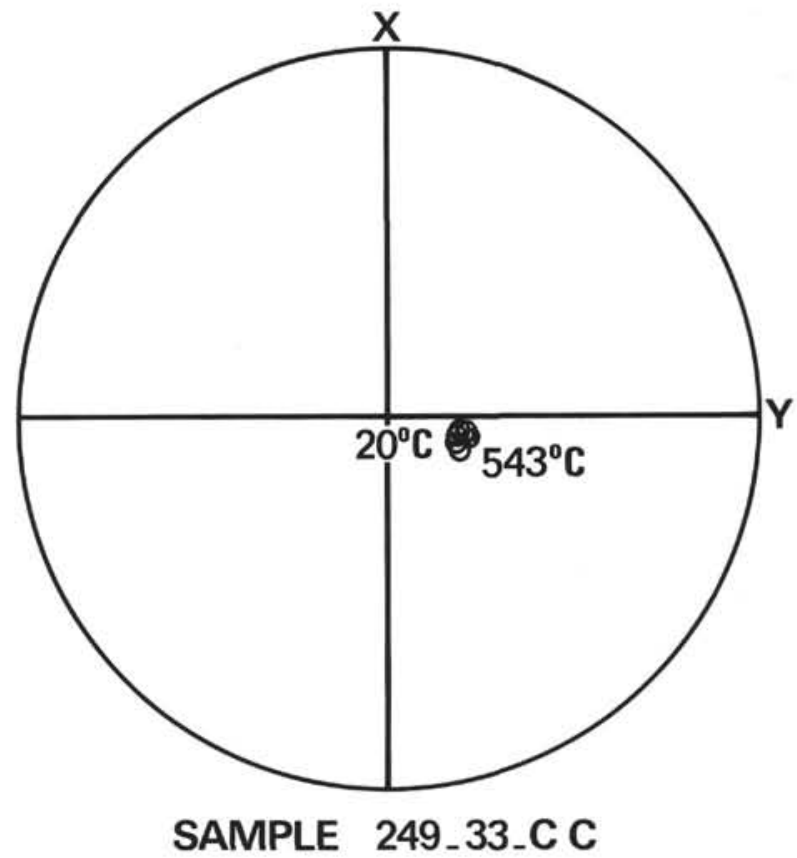

SAMPLE 249_33_C C

Figure 9. Variation of direction of remanence during thermal demagnetization of samples from Sites 245 and 249. 


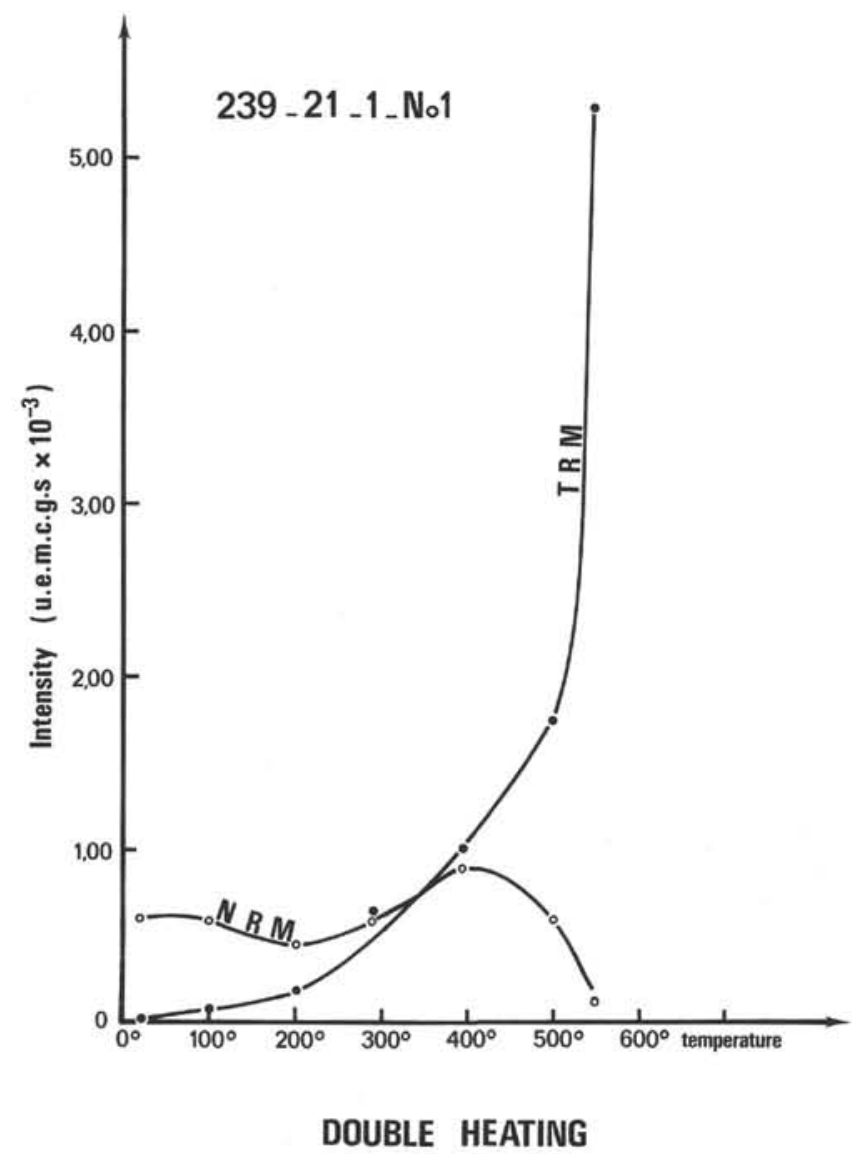

Figure 10. TRM acquired between $\mathrm{T}^{\circ}$ and $20^{\circ} \mathrm{C}$ and NRM left after heating at $\mathrm{T}^{\circ} \mathrm{C}$ for Sample 239-21-1, 12-18 cm (no. 1).

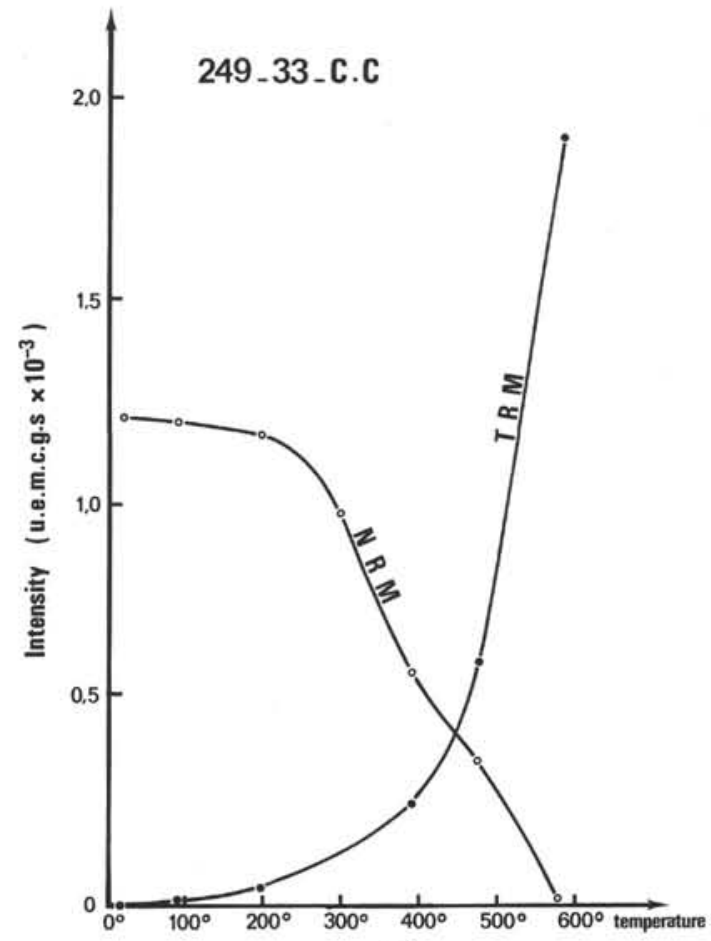

(a)

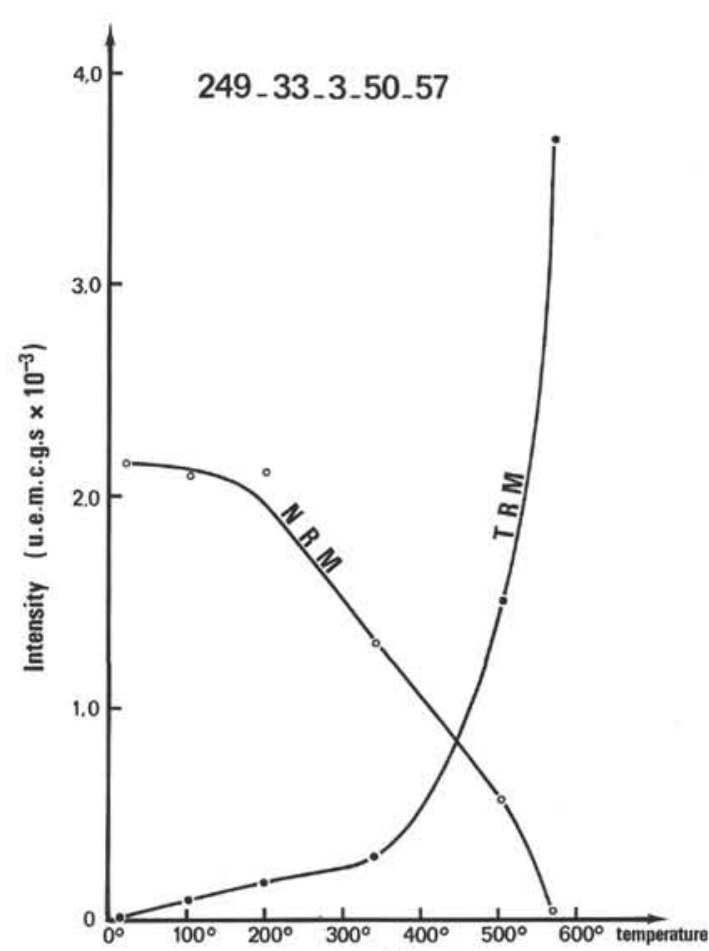

(b)

Figure 11. TRM acquired between $\mathrm{T}^{\circ}$ and $20^{\circ} \mathrm{C}$ and NRM left after heating at $\mathrm{T}^{\circ} \mathrm{C}$ for Samples 249-33, CC and 249-33-3, 50-57 cm. 

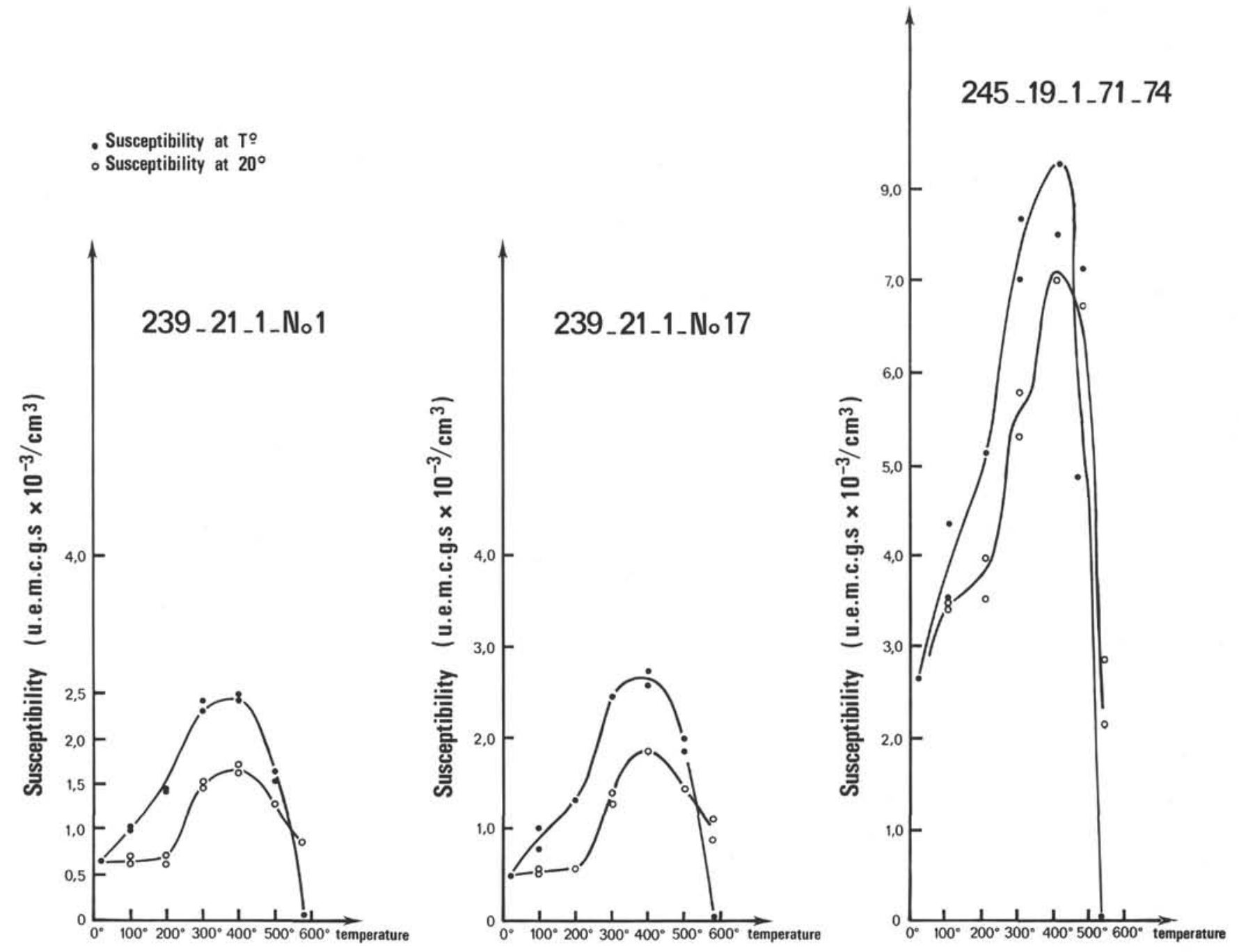

\section{VARIATION OF SUSCEPTIBILITY WITH TEMPERATURE}

Figure 12. Variation of susceptibility with temperature for Samples 239-21-1, 12-18 cm (no. 1); 239-21-1, 137-148 cm (no. 17); and 245-19-1, 71-74 cm. 
- Susceptibility at To

- Susceptibility at $20^{\circ}$

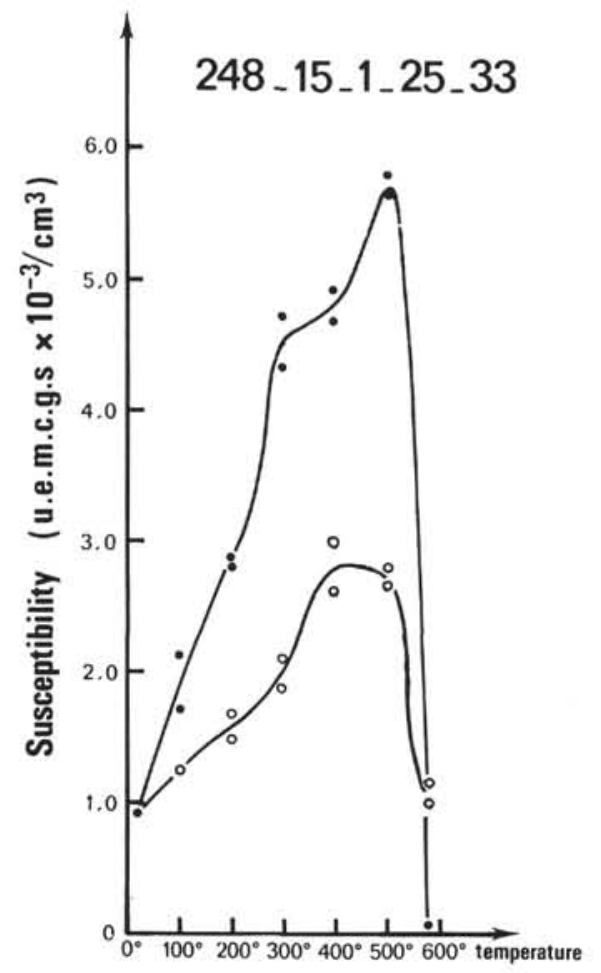

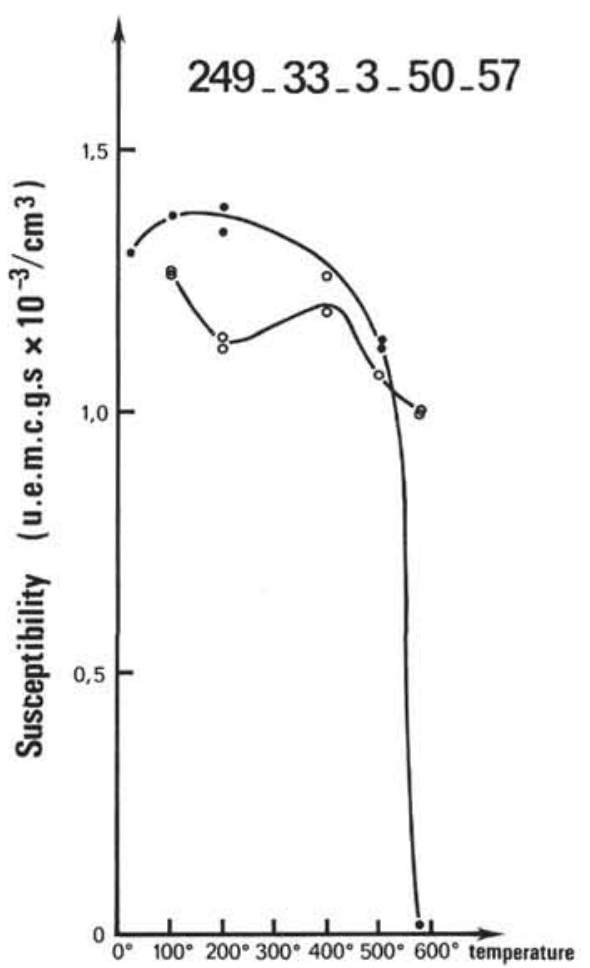

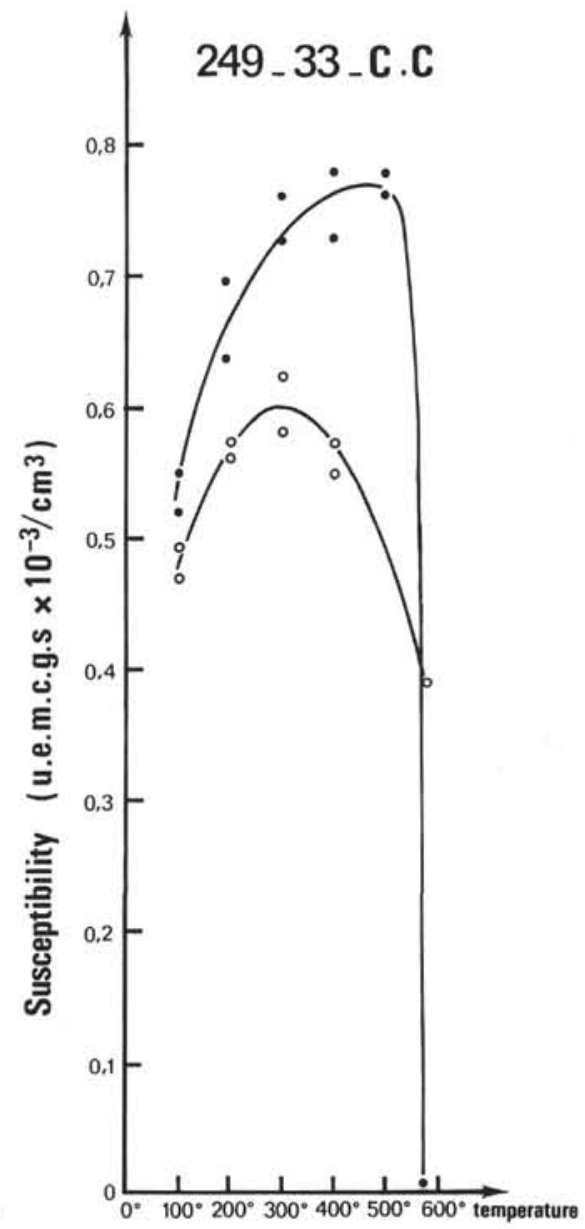

\section{VARIATION OF SUSCEPTIBILITY WITH TEMPERATURE}

Figure 13. Variation of susceptibility with temperature for Samples 248-15-1, 23-33 cm; 249-33-3, 50-57 cm; and 249-33, CC. 

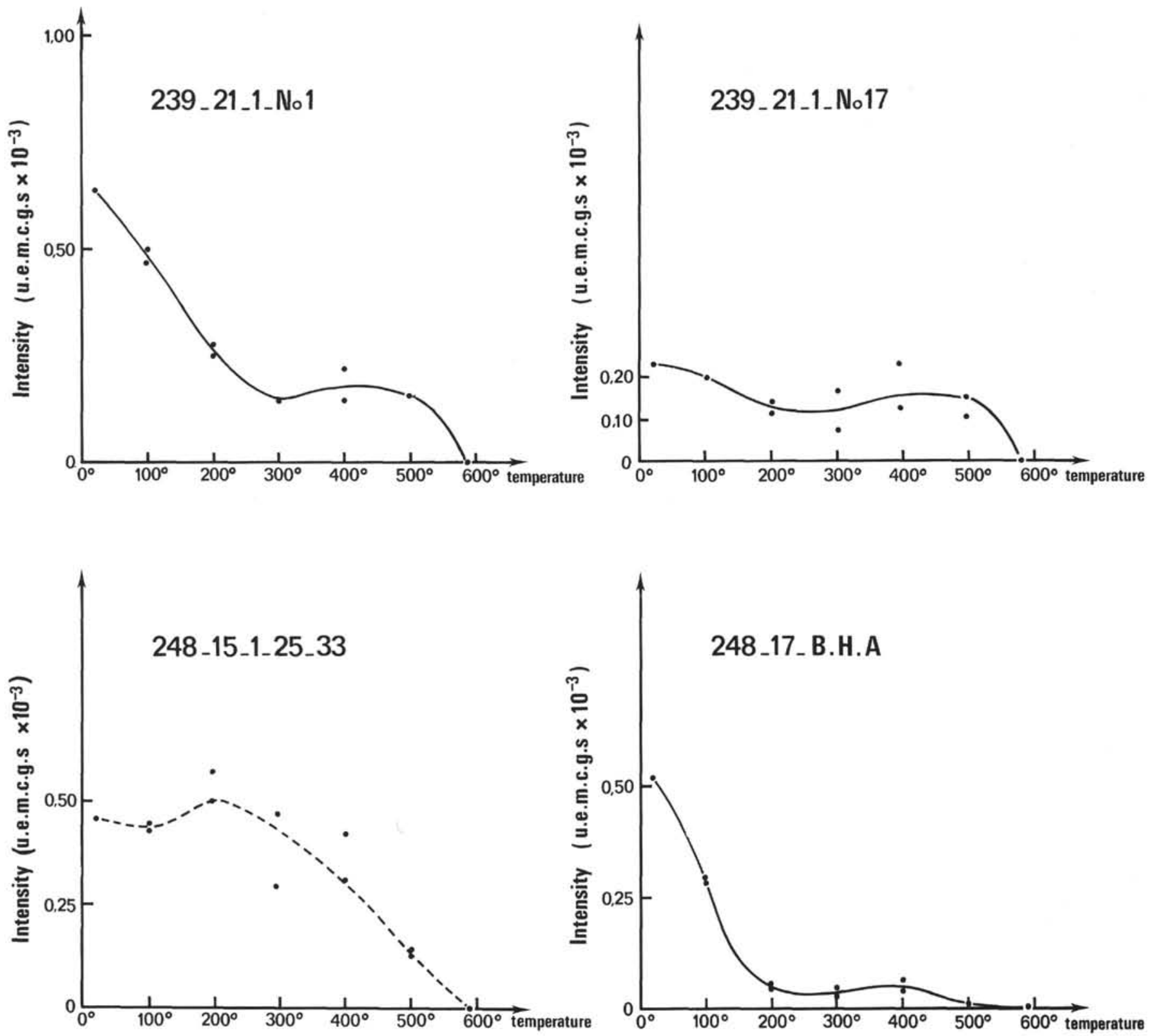

\section{CURIE TEMPERATURE ANALYSIS}

Figure 14. Curie temperature analysis for samples collected at Sites 239 and 248. 

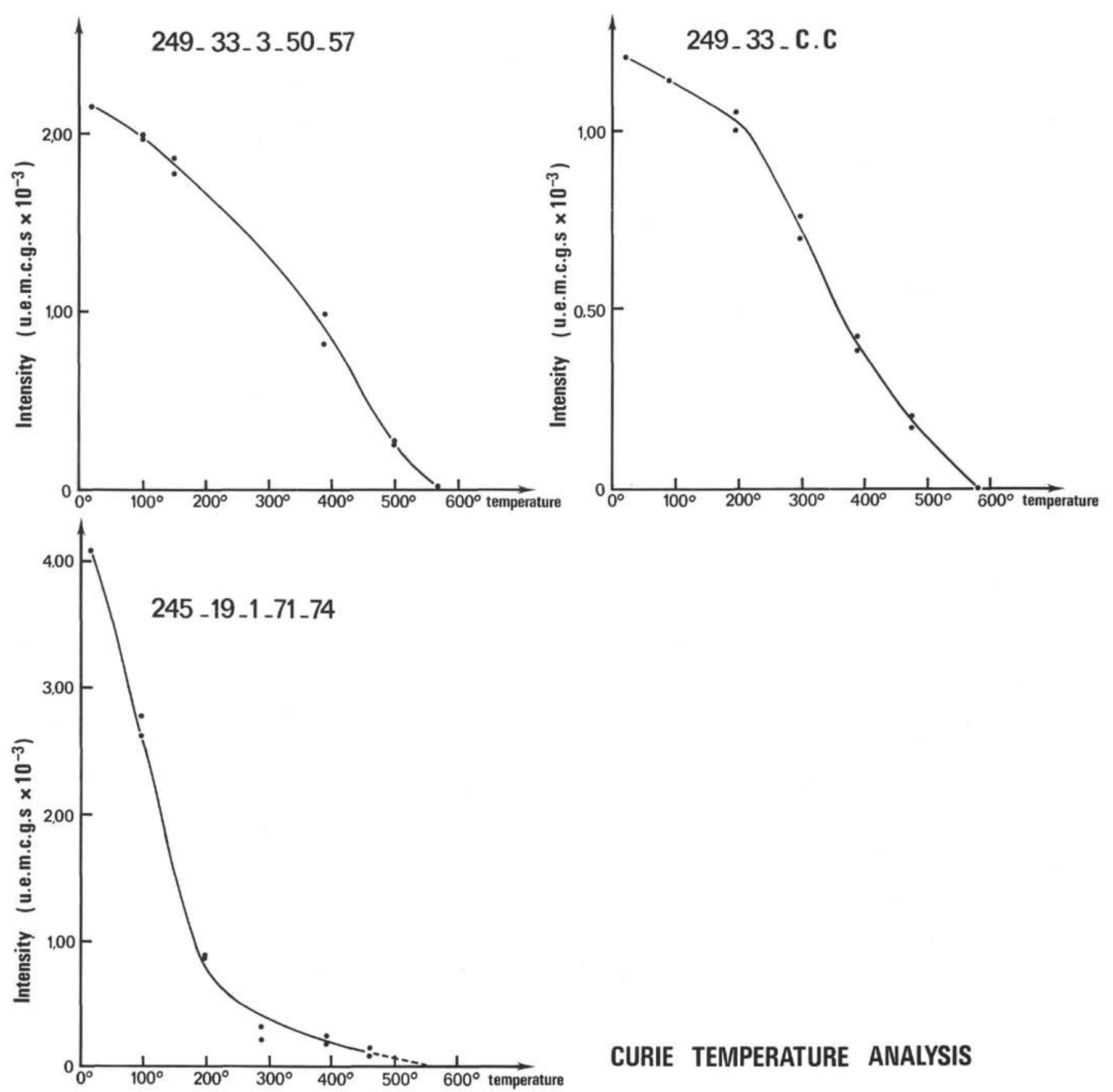

\section{CURIE TEMPERATURE ANALYSIS}

Figure 15. Curie temperature analysis for samples collected at Sites 245 and 249. 